\title{
Selection effects in roll call votes
}

\section{Working Paper}

\section{Author(s):}

Hug, Simon

Publication date:

2006

Permanent link:

https://doi.org/10.3929/ethz-a-005388995

Rights / license:

In Copyright - Non-Commercial Use Permitted

Originally published in:

CIS working paper 15(2006) 


\section{uni | eth | zürich \\ Center for Comparative and International Studies (CIS)}

\section{Working Paper No 15, 2006}

Published by the Center for Comparative and International Studies (ETH Zurich and University of Zurich)

\section{Selection Effects in Roll Call Votes}

Simon Hug

University of Zurich 


\title{
Selection Effects in Roll Call Votes*
}

\author{
Simon $\mathrm{Hug}^{\dagger}$ \\ CIS, IPZ, Universität Zürich
}

First version: March 2005, this version: May 7, 2006

\begin{abstract}
An increasing number of studies comparing legislatures relies on analyses of roll call votes. These analyses are used to infer characteristics of the way in which the legislature works and how their members vote. These inferences are problematic, however, if not all votes in parliament are recorded or the recorded votes are systematically distinct from the rest of the votes. Neglecting the way in which roll call votes are triggered or decided may result in selection bias. In this paper I discuss these problems of selection bias regarding various rules employed in legislatures which may lead to roll call votes. I then present evidence for these selection biases from a unique source of electronically recorded votes, namely all votes decided on between 1995 and 2003 in the Swiss lower house. A careful analysis illustrates to what extent commonly used figures on party discipline are biased because of the selective nature of roll call votes. I also propose a simple way how to correct for these biases, which performs adequately well.
\end{abstract}

* An earlier version of this paper was prepared for presentation at ECPR Joint Sessions of Workshops (Granada, Spain, April 14-19, 2005), while parts of it were presented at the "European Governance Conference" (Halle Institute, Emory University, Atlanta, February 1617, 2006), a seminar at Trinity College (Dublin), at the conference "Legislative Behavior in Europe, the US, and Beyond" (UCSD, San Diego, April 14-15, 2006) and the annual meeting of the Midwest Political Science Association (Chicago, April 20-23, 2006). Thanks are due to the participants at these events for their helpful comments, as well as the Swiss Parliamentsdienste and especially Andreas Sidler, who provided the main bulk of the empirical data used here and helped us using it. Michael Hermann, Hans Hirter, and Tobias Hohl made available additional data, while Ladina Caluori, Tobias Schulz and Franziska Spörri provided gratefully appreciated research assistance. Many of the ideas presented here have strongly benefited from discussions with Cliff Carrubba and Matt Gabel. Partial financial support from the Swiss National Science Foundation (Grant 100012-111909/1) is gratefully acknowledged.

$\dagger$ Center for Comparative and International Studies; Institut für Politikwissenschaft; Universität Zürich; Hirschengraben 56; 8001 Zürich; Switzerland; phone +41 (0)44 63450 90/1; fax: +41 (0)44634 5098; fax: +41 (0)44634 5098; email: simon.hug@access.unizh.ch 


\section{Introduction}

Roll call votes in parliaments may yield important insights on various aspects of political systems. They may inform us on the apparent conflict lines in parliaments (e.g., Poole and Rosenthal, 1997), the cohesion of party groups (e.g. Loewenberg and Patterson, 1979; Harmel and Janda, 1982; Bowler, Farrell and Katz, 1999; Depauw, 2003; Depauw and Martin, 2005), ${ }^{1}$ the representativeness of members of parliaments (MPs) (e.g., Bartels, 1991; Levitt, 1996), etc. Thus, it cannot astonish, that studies using roll call votes from parliaments at the national or even supranational (e.g., Attina, 1990; Brzinski, 1995; Voeten, 2000; Hix, Noury and Roland, 2005; Hix, Noury and Roland, 2006 forthcoming) level have become more frequent.

With few exceptions an important potential problem of such studies is, however, neglected or glossed over. Namely, in most parliamentary settings not all votes are recorded as roll call votes. More precisely, while some parliaments like the US Congress record and publish all votes (e.g., Poole and Rosenthal, 1997), others like the Swiss lower house record all votes but publish only a subset, while still in others like the European parliament (EP) recorded votes have explicitly to be requested. While using roll call votes for the purposes discussed above is rather unproblematic for parliaments recording and publishing all votes (though see Snyder, 1992; Londregan, 2000; Cox and McCubbins, 2005), this is hardly the case for all other parliaments. The reason is simply that the set of published votes in these cases is a subset of all votes by MPs, and the way in which this subsample is formed may bias our substantive results. For instance, if party leaders request roll calls to discipline their rank-and-file, it is likely that on the one hand roll call votes will take place mostly for contentious decisions and, on the other hand, roll call votes will also discipline the members of a party. ${ }^{2}$ Which of these possible effects dominates is an empirical and partly theoretical matter. If

\footnotetext{
${ }^{1}$ I will use the terms party cohesion and party discipline as synonymous in this paper, even though there are good reasons to distinguish them (Hazan, 2003; Bowler, 2000). This allows me some variation in the terms used and eschews the question what the cohesion scores actually measure. Since I focus on these scores in this paper, how cohesion is maintained is only indirectly, though importantly, relevant for the arguments that follow.

${ }^{2}$ This argument forms the underpinning of studies finding that candidate selection affects behavior of legislators and thus party cohesion (e.g., Gallagher, 1988, 15). Only if party leaders can observe in roll-call votes the behavior of their party colleagues can the former affect the behavior of the latter.
} 
the two effects do not cancel each other out, however, measures of party cohesion based on published votes will be biased. Similarly, if only a subset of all votes is recorded, for instance, final votes, particular characteristics of these votes may also hamper our inferences. Suppose only final votes on bills are published. It might be that at that time in the legislative process all conflictive elements have been resolved or that this final vote is a largely formal matter. As a consequence we would expect the set of final votes to hardly give us an accurate reflection of parliamentary conflict.

In this paper I discuss these problems of selection bias and offer empirical evidence, that these biases may be considerable. I first discuss in the next section the ways in which roll call votes have been used in the literature. In section three I discuss the different ways in which roll call votes occur in parliaments around the world. Based on this overview, I show how results from empirical studies are subject to potential selection biases depending on how roll call votes are recorded and published. In section four I illustrate and document these biases for two legislatures (1995-1999, 1999-2003) of the Swiss lower chamber. The empirical analysis relies on all votes in this parliamentary chamber, which allows us to distinguish parliamentary behavior in votes not published, those published automatically, and those requested on the demand of members of parliaments. In section five I offer some initial results based on an empirical model addressing these selectivity problems when studying the cohesion of party groups before concluding in section six.

\section{The use of roll call votes in empirical studies}

Roll call votes provide an important source of information for various aspects of political systems. Consequently, political scientists have used these recorded votes for various purposes and in various contexts. Of tantamount importance in the development of these studies is certainly the scholarly work on the US Congress. Given that all votes in both the House of Representatives and the Senate are recorded and published, ${ }^{3}$ congressional scholars have a long tradition of using this information. One of the central research questions addressed with the help of roll call votes consists of assessing the relevant conflict lines in both

\footnotetext{
${ }^{3}$ Below I provide a detailed overview over the various ways employed to record and publish votes in a series of countries.
} 
houses of Congress. Poole and Rosenthal's (1985) work was of central importance in the development of this literature. ${ }^{4}$ Similarly, early work on the US Congress demonstrated the comparatively rather low levels of party discipline (e.g., Loewenberg and Patterson, 1979; Harmel and Janda, 1982). Again, this information was largely obtained on the basis of roll call analysis.

Both of these types of analysis were quickly adapted to other contexts than the US Congress. Loewenberg and Patterson (1979), Janda (1980, 118-119) and Cox (1987) used divisions in the British parliament to underline important changes having occurred in the way in which this institution functioned. Similarly, other scholars have assessed the degree of party cohesion in Latin American legislatures (Amorim Neto, 2002; Jones, 2002; Nacif, 2002; Desposato, 2003; Morgenstern, 2003), in the Danish parliament (Skjaeveland, 1999), the Swiss Parliament (Vasella, 1956; Lüthi, Meyer and Hirter, 1991; Jeitziner and Hohl, 1997; Hermann, Leuthold and Kriesi, 1999; Kriesi, 2001; Hug and Schulz, 2006 forthcoming), the European parliament (Attina, 1990; Kreppel, 2002; Brzinski, 1995; Hix, Noury and Roland, 2005), just to name a few. Similarly, a series of scholars has attempted to assess the ideological conflict lines appearing in roll call votes in parliaments other than the US Congress. Studies on Latin American parliaments (Londregan, 2000), the Swiss Parliament (Jeitziner and Hohl, 1997; Hermann, Leuthold and Kriesi, 1999; Kriesi, 2001; Hug and Schulz, 2006 forthcoming) or the European parliament (Hix, 2001; Noury, 2002; Hix, Noury and Roland, 2006), are just a few examples for this trend.

Both of the main uses of roll call votes, namely the assessment of party cohesion and the determination of conflict lines present in parliaments, have also generated many debates. Concerning the dimensional analysis debates exist regarding the appropriate theoretical model and the resulting empirical estimation method used to determine the conflict dimensions. While the model championed by Poole and Rosenthal (1997) relies in essence on a probit specification to link the underlying ideology dimensions to particular voting decisions by MPs, Heckman and Snyder (1997) favor a linear probability model. More recently, Londregan (2000) has argued that the models employed to analyze roll call votes should also take into consideration the strategic context of these votes. Consequently, the rules of procedures, the role of committees, etc. are likely to affect considerably

\footnotetext{
${ }^{4} \mathrm{I}$ do not aim at providing a detailed overview of this literature here, since this task is admirably carried out by Poole and Rosenthal (1997).
} 
the MPs' voting behavior on the floor. Similarly, relying on Bayesian statistics, (Clinton, Jackman and Rivers, 2004) and Jackman (2004) offer an alternative way to assess the dimensionality of conflict in parliaments. ${ }^{5}$

Similar debates focus on the ways in which the cohesion of political parties or party groups in parliaments should be measured. The most frequently used such measure is the so-called Rice-index (e.g., Rice, 1925), which simply corresponds to the following formula:

$$
R I_{i}=\frac{\left|Y E S_{i}-N O_{i}\right|}{Y E S_{i}+N O_{i}}
$$

where $Y E S_{i}$ and $N O_{i}$ are the number of votes in favor, respectively against a particular proposal $i$. While the Rice-index is calculated for each vote, most often the average value of this index is of interest. Alternative measures attempt to correct for biases for small parties (Desposato, 2003; Desposato, 2005), a larger set of voting options (Attina, 1990; Hix, Noury and Roland, 2005; Desposato, 2006), or other aspects.

While all these various ways to improve upon our analysis of roll call votes are important, especially for comparative work the question arises whether roll call votes in one context are the same as roll call votes in another. This relates to the question of which parliamentary votes are recorded and published, and thus available for researchers. For valid inferences on partisan and parliamentary behavior, this set of available votes should correspond either to the total population of votes or to a subset selected in such a way that it does not affect our conclusions.

\section{Institutions under which roll call votes occur and selection biases}

The way in which roll call votes occur in parliaments varies quite dramatically. Many of these differences have to do with the traditions of parliamentary life in a particular country (e.g., Interparliamentary Union, 1986). An early overview for West European countries appeared in Saalfeld (1995). Similarly, Carey (2004) provides a detailed discussion of the institutions employed in Latin American

\footnotetext{
${ }^{5}$ Poole (2005) provides a very useful overview over these various methods.
} 
parliaments. Both contributions clearly demonstrate that roll call votes occur under a wide array of institutional provisions. Building on these sources and complementing them with information from Interparliamentary Union (1986) I provide a summary of these institutions for 92 countries and their parliamentary chambers in table $1 .^{6}$

Table 1 clearly suggests that the analysis of roll call votes may be potentially problematic, given that the available information fails to cover all votes taken in parliament. More precisely, in only 20 of the 92 countries considered are all parliamentary votes published. Thus, strictly speaking for research questions dealing with party cohesion and the dominant conflict lines, only data from these 20 countries provide unambiguous results. Unambiguous results, namely none, are also to be expected from the 23 countries in which no parliamentary votes are published. The remaining 49 countries have either only particular votes that are published and/or only those requested. The former is the rule in 43 countries, while the latter applies to 28 countries of the 49 countries. Hence, in six countries both rules apply.

Table 1: Parliamentary voting in 92 parliaments

\begin{tabular}{l|l}
\hline \hline Parliaments with no publication & 23 \\
Parliaments publishing all votes & 20 \\
Parliaments publishing specific votes & 43 \\
Parliaments publishing requested roll calls & 28 \\
\hline \hline
\end{tabular}

The analysis of roll call data in these latter 49 countries, among them Switzerland, but also the European Union with the European parliament, may be problematic, if inferences to general MP behavior are attempted. Consider a parliament that only publishes a subset of parliamentary votes. If these votes do not form a random subset of all the votes taken in the parliament considered, our inferences about MP behavior may be considerably biased.

Similarly, if a parliament only publishes roll calls which have been requested by particular actors, it becomes important to understand the reasons which lead an actor to ask for a recorded vote. Only if these motivations are completely unrelated to the research question at hand, can we expect unbiased inferences from the subset of votes we can study. This, however, seems a rather unrealistic

\footnotetext{
${ }^{6}$ The detailed country specific information appears in table 6 in the appendix. This table relies on a rather eclectic set of sources, and thus should only be considered as illustration.
} 
assumption to make, as the careful analysis of one year's worth of legislative work in the European Parliament by Gabel and Carrubba (2004) and Carrubba, Gabel, Murrah, Clough, Montegomery and Schambach (forthcoming) proves. These authors can show, that the recorded votes differ along several dimensions (e.g., committee origin, procedure, etc.) from the remaining votes in the European parliament. Such differences may affect many conclusions reached on the cohesion of the party groups (e.g., Kreppel, 2002; Hix, Noury and Roland, 2005; Hix, Noury and Roland, 2006 forthcoming) or the dimensionality of the political space in the European parliament (e.g., Hix, 2001; Noury, 2002; Hix, Noury and Roland, 2006). ${ }^{7}$

While congressional scholars (e.g., Poole and Rosenthal, 1997, 56) appeared to be aware at least in part of possible problems of selection, this caution largely disappeared in most comparative studies. Thus scholars studied the dominant conflict lines in parliament using various methods and also the cohesion of parties without taking into account the ways in which the data employed were generated. While often a shameful reference to the problem appears in empirical studies to this problem, it is hardly addressed directly.

Important attempts in this direction appears in the work on the European parliament. As discussed below, in the European parliament roll call votes have to be requested by the party groups. Their decision to call for a vote, however, is hardly random, and thus the data available to researchers is quite clearly a possibly biased subset of all votes in the European parliament. Why this subset might be biased is nicely demonstrated by Carrubba and Gabel (1999) in a theoretical model attempting to explain the occurrence of roll call votes in the European parliament. Quite clearly, the expectations of the party group leadership are of tantamount importance, putting into question many insights about the party groups' cohesion.

\footnotetext{
${ }^{7}$ Gabel and Carrubba (2004) offer a detailed comparison of roll call votes and the remaining votes having occurred in the European parliament.
} 


\section{Roll call votes and selection bias: Swiss em- pirics}

These expected selection effects can nicely be demonstrated with the help of a unique dataset of parliamentary votes. The analysis of roll call votes in the Swiss parliament has been hampered for a considerable time by their infrequent nature. An early study (Vasella, 1956) covering the years 1919 (introduction of proportional representation as electoral system for the lower house) until 1953 could only unearth 108 recorded and published votes. A more recent study (Lüthi, Meyer and Hirter, 1991) covering 1971-1989 analyzed 134 votes to assess the cohesion of parties in the National Council. Recorded and published votes are even rarer in the upper house, since Von Wyss's (2003) study finds only four such votes. Only more recent studies (e.g. Jeitziner and Hohl, 1997; Hermann, Leuthold and Kriesi, 1999; Kriesi, 2001; Hug and Schulz, 2006 forthcoming) rely on larger sets of recorded and published votes.

Figure 1: Recorded and published votes 1919-1991

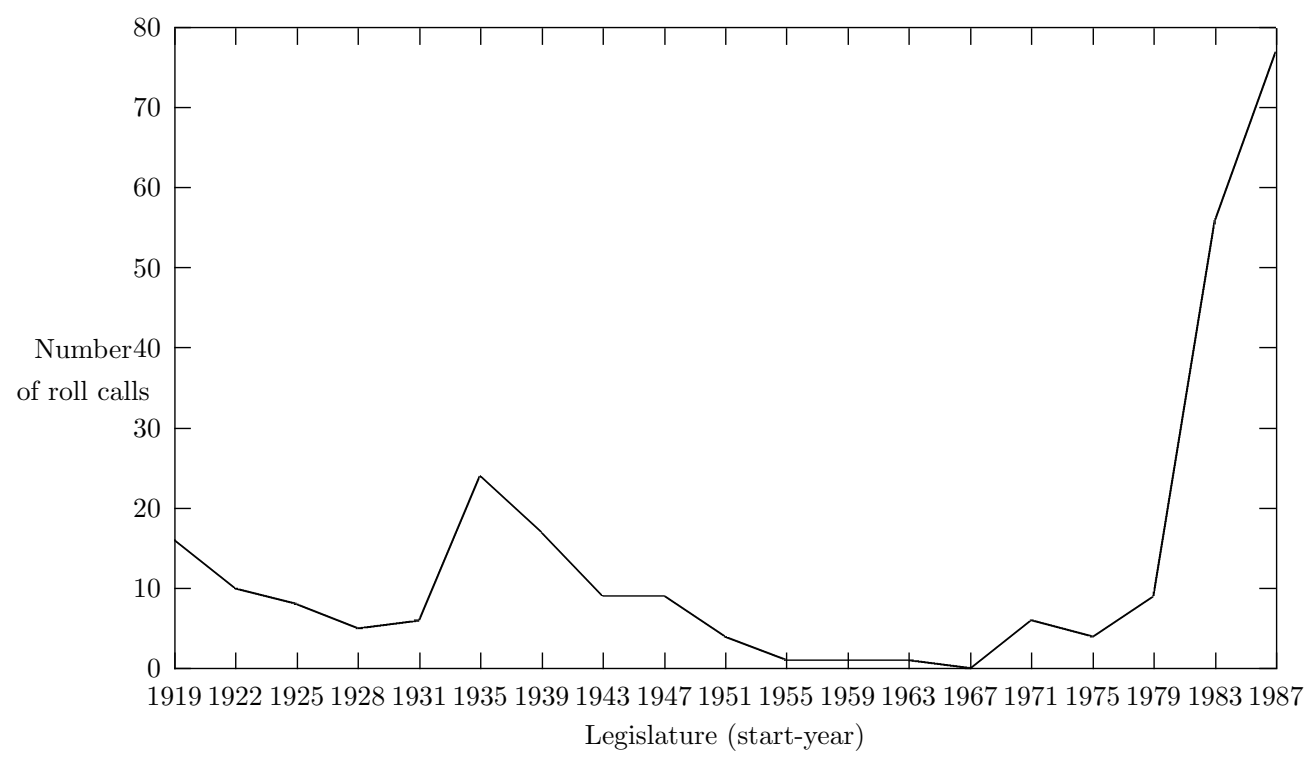

The reason for this is that until 1994 the only way in which votes in the lower house could be published was if a certain number of members of parliament requested a roll call vote. All remaining votes were by show of hands and not recorded. In 1994 the lower house introduced an electronic voting system that 
records all votes by the MPs. While all votes are recorded, only a subset of them is published. More precisely, only votes on emergency measures, final votes, and total votes are published automatically. In addition, as before 199430 members of parliament may request that a roll call, which is published, is taken. Thus, not surprisingly, in the legislative period between 1991 and 1995576 roll call votes were published, between 1995 and 1999 945, and finally between 1999 and 2003 1171.

These numbers for the most recent legislative periods are dramatically higher than those of earlier periods. Figure 1 demonstrates that quite a few roll call votes occurred in the interwar period, but after World War II, the number declined rapidly. Only with the late 1960s the possibility to request recorded votes seems to have been rediscovered (Lüthi, Meyer and Hirter, 1991). Interestingly enough, the introduction of the electronic vote and the resulting increase in published votes, seems to have been foreshadowed by a dramatic increase in requests for recorded votes in the 1980s.

As figure 1 already illustrates, the number of roll call votes has increased quite dramatically. Figure 2 underlines this trend and emphasizes, that both the share of requested roll calls and the share of automatic roll calls has increased. The increase in the former may only be explained by a decrease of votes on details of particular bills, parliamentary motions, etc., which are not subject to automatic publication. The increase in the latter, following the trend depicted in figure 1 demonstrates that MPs have found a liking for demanding recorded votes.

The information depicted in figure 2 relies on a unique dataset, namely information on all parliamentary votes recorded in the Swiss lower house in two legislatures. This dataset covers not only those votes recorded and published because they were requested or required, but comprises information on all MPs' voting decisions. ${ }^{8}$ Hence, this dataset allows us to directly assess the likely biases introduced in empirical analyses if only a subset of votes is considered. For this I will focus on the cohesion of the party groups present in the lower chamber of the Swiss parliament. ${ }^{9}$

\footnotetext{
${ }^{8}$ The Swiss Parlamentsdienste made this dataset available to us, under the condition of respecting the confidentiality of the individual votes. Hence, I cannot make accessible the data used and can only offer averages and other summaries of the data used.

${ }^{9}$ Obviously, biases are also to be expected in dimensional analysis of roll call votes, as the rather powerful analysis of the European parliament by Gabel and Carrubba (2004) and Carrubba, Gabel, Murrah, Clough, Montegomery and Schambach (forthcoming) illustrates.
} 
Figure 2: Share of automatic and requested votes in the National Council 19951999 and 1999-2003

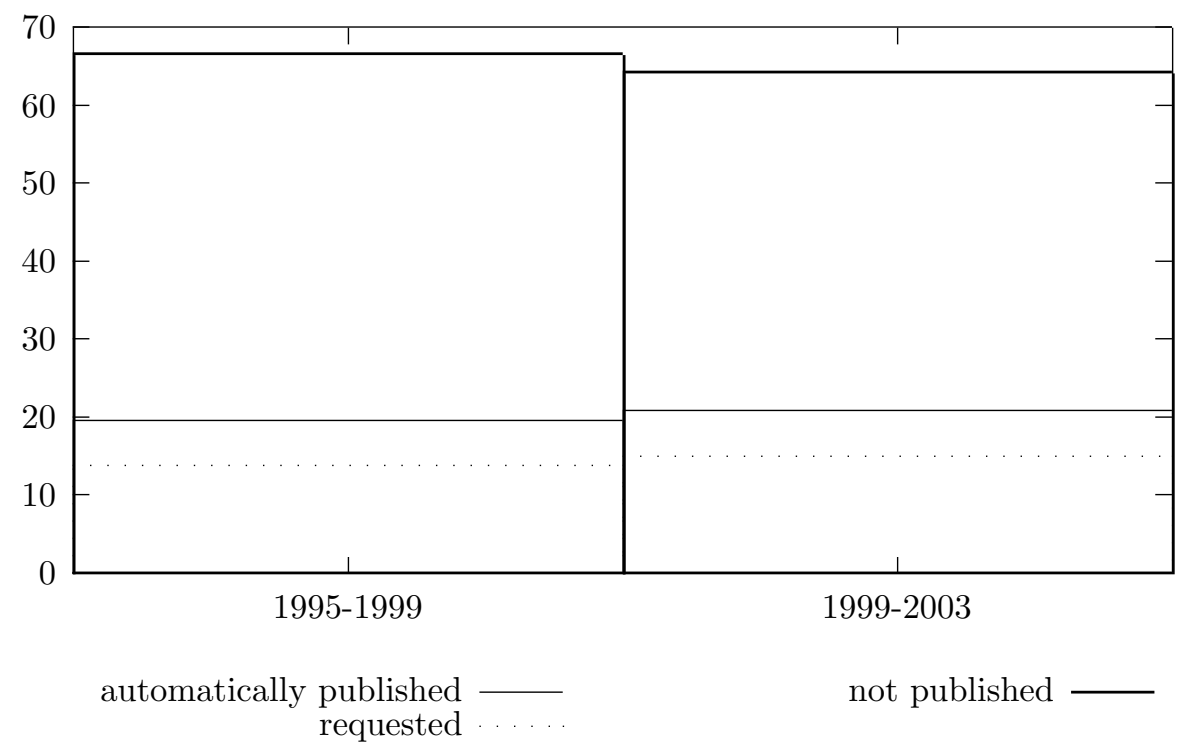

The main party groups are formed around the parties represented in the executive, namely the Christian-democrats (CVP), the Radicals (FDP), the People's Party (SVP), and the Social-democrats (PS). Of lesser importance, numerically at least, are the Greens (GPS), the Liberals (PLS), and the party group of the Alliance of Independents and the Evangelical Party (LdU/EVP). Finally, one party group only existed in the legislature between 1995 and 1999, and then disappeared from the political scene, namely the Freedom party (formerly known as the Car drivers' party). ${ }^{10}$

Earlier studies of party cohesion (e.g., Vasella, 1956; Lüthi, Meyer and Hirter, 1991) highlighted the comparatively rather high party discipline in the Swiss lower house. This contrasts with the often attempted assimilation of the Swiss political system with presidential democracies (e.g., Persson and Tabellini, 2003), which are often characterized by low party discipline. As noted above, however, these studies rely on a very small, and possibly biased subsample of votes in the lower house of the Swiss parliament.

Table 2 reports the average values of the Rice-index for the major parties from

\footnotetext{
${ }^{10}$ Good overviews over the political parties can be found in Ladner (1999), Ladner and Brändle (2001) and Ladner (2004).
} 
Vasella (1956) and Lüthi, Meyer and Hirter (1991) while updating these numbers with the more recent legislative periods. As noted above, in the legislative periods covered in the first four columns, the Rice-index can only be computed for roll call votes requested by MPs. In the legislative period between 1991 and 1995 until spring 1994 this was still the case, while starting with the spring 1994 legislative session, final votes, total votes and votes on urgent measures were automatically published. Finally, for the last two legislative periods reported in table 2 the Rice-index is based on all votes in the Swiss lower house.

Overall, the picture transpiring from table 2 supports the conclusion of other scholars emphasizing the rather high party discipline in the Swiss lower house. When looking at the changes over time we find no overarching trend, but clearly some differences appear, which seem related to the set of votes on which the cohesion index was calculated. With the exception of the Social-democrats (SP) and the smaller parties we find a peak in the average Rice-indices in the 19911995 legislative period. But only in this period are the Rice-indices based on a combination of requested roll calls and automatically published votes. Hence, we need to look more closely at the way in which party cohesion depends on the type of vote.

To assess whether employing only requested votes to assess party discipline is problematic, I compare the various types of votes for two legislatures. Thus, in table 3 I report the mean values of the Rice-indices for all party groups present in the 45th (1995-1999) and 46th (1999-2003) legislature. More precisely, in columns 2 and 3 I report the mean Rice-indices for votes that are recorded though not published. In columns 4 and 5 I list the mean Rice-indices for the automatically recorded and published votes, while columns 6 and 7 list the same values for the requested votes. Finally, in the last four columns I report the overall averages as well as the results of an F-test for equal means across the three categories of votes in parliament. 


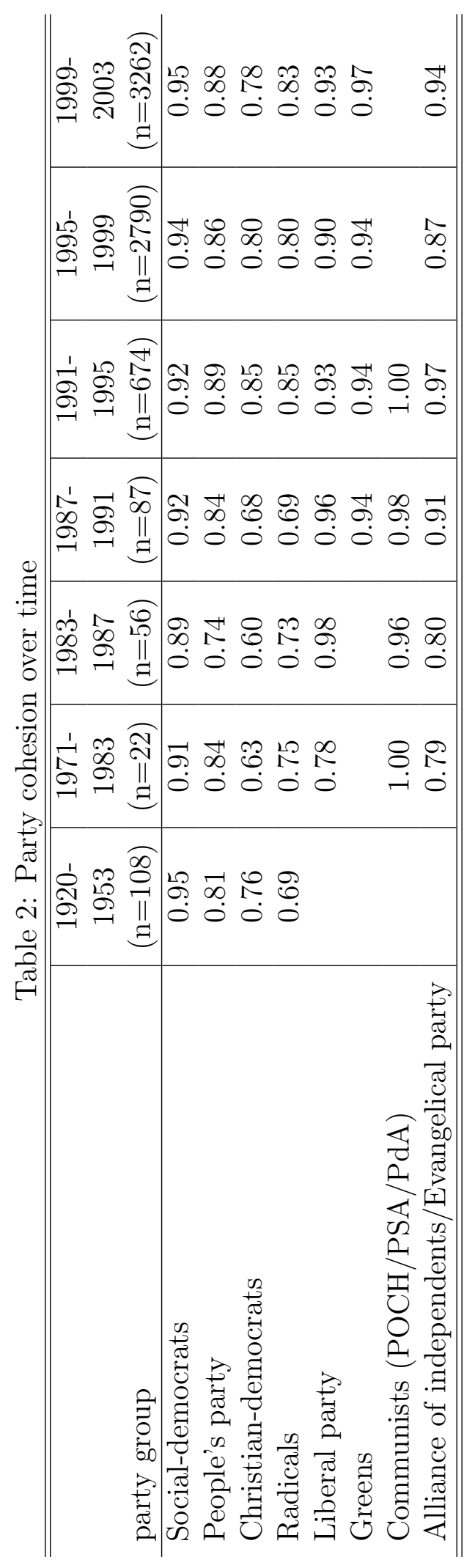


Table 3 shows some interesting patterns. First of all, for almost all party groups the average party cohesion scores vary systematically and markedly among the different types of votes. Only for three parties, namely the People's party (45th legislature), the Greens (both legislatures), and the Alliance of independents (46th legislature) ${ }^{11}$ does the nature of the votes not appear to affect systematically the level of party cohesion (last two columns in table 3). For the remaining parties we find a persistent pattern. Party cohesion is systematically highest for those votes that are automatically recorded and published. Cohesion is much lower in unpublished votes and even more so in votes requested by a set of MPs.

This clearly illustrates that relying on a subset of roll call votes biases our inferences on the cohesion of party groups. In the present case, it appears that the automatically published votes that comprise final and total votes, as well as votes on urgency measures, are votes for which conflict has already been resolved in earlier stages of the legislative process. ${ }^{12}$ Given that in all remaining votes intra-party conflict is higher, published votes give hardly an accurate picture.

The finding that roll call votes requested by MPs are the most divisive for party groups suggest that of the two mechanisms discussed above the selection effect seems to dominate. That is, MPs request roll call votes if party groups are divided. Ideally, we would like to assess whether the identity and party affiliation of the MPs requesting a roll call affects the cohesion of party groups differently.

\footnotetext{
${ }^{11}$ In this last case, however, the very small number of votes used to determine the Rice-index is probably the main explanation for the lacking difference.

${ }^{12}$ Obviously, though initially not obvious to me, it might also be the case that in final votes parties engage much more in whipping their members and thus achieve a higher party discipline. I thank Gail McElroy for suggesting this interpretation to me.
} 


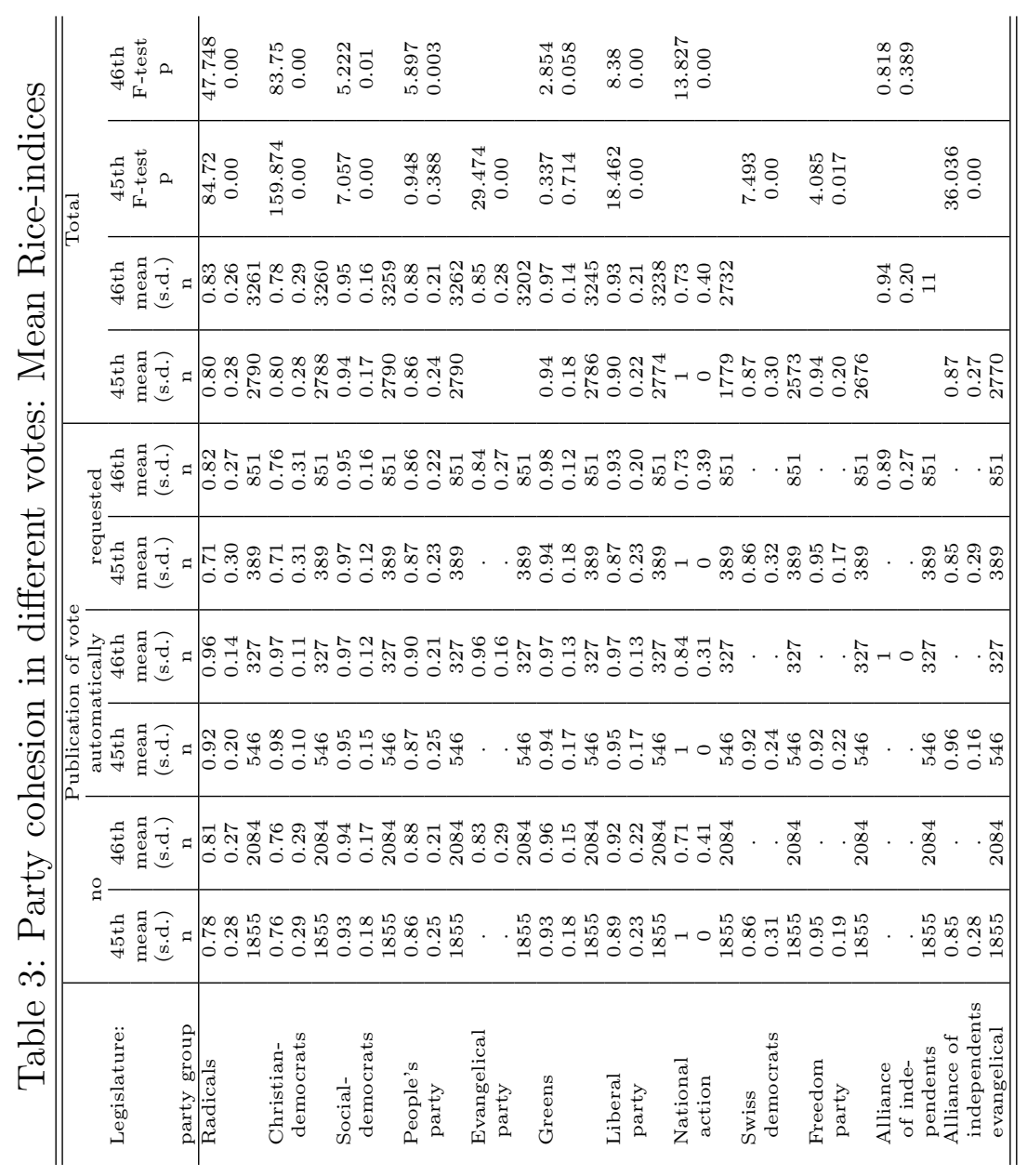




\section{Roll call votes and selectivity}

To fix this problem of selection bias, theoretical information on the selection process is necessary. This information then can be used to correct for possible selection biases through the estimation of a selection equation. Unfortunately, our dataset covering all votes in the Swiss lower house contains only little contextual information. First of all I cannot identify the MPs having called for a roll call vote. Second, the content of the various votes is sketchy at best. This type of information, combined with possible additional information, can be used, however, to correct our inferences both on the cohesion of party groups and the conflict lines present in parliaments. ${ }^{13}$

To demonstrate how this can be done, the following simple setup seems useful. Assuming only binary decisions (omitting abstention and non-votes) with $y \in$ $\{0,1\}$ (with $1=$ yea and $0=$ nay) most research questions dealing with roll calls can be framed in the following two equations:

$$
\begin{gathered}
y_{i}=\left\{\begin{array}{l}
1 \text { if } y_{i}^{*}>0 \\
0 \text { if } y_{i}^{*} \leq 0
\end{array}\right. \\
Y^{*}=X \beta_{X}+W \beta_{W}+Z \beta_{Z}+\epsilon
\end{gathered}
$$

In matrix notation $X$ stands for the policy positions (possibly unobserved) of the MPs, $W$ for variables related to party discipline (and possibly vote characteristics) and $Z$ for constituency and other factors possibly explaining the votes of MPs. Equation 3 we can also highlight what the two questions often asked in studies on roll-call votes wish to achieve. Studies on the dimensionality of the parliamentary policy space attempt to identify $X$ and its effect $\left(\beta_{x}\right)$ on the individual MP's voting decisions.

Studies on party discipline attempt to assess the relative weight of $W$ (thus $\left.\beta_{W}\right)$ in explaining the vote decisions of MPs. If parties were completely cohesive, $\beta_{Z}=\mathbf{0}$, while $\beta_{X}$ should only differ from $\mathbf{0}$ in so far as members of the same party share their ideological position.

\footnotetext{
${ }^{13}$ Hug and Wisler (1998), Brehm (2000), and Hug (2003) illustrate how this can be done in different contexts.
} 
With the small inconvenience that we do not observe $X$, normally, equation 3 could easily be estimated to find answers to the questions raised above. An additional problem relates, however, to the availability of the data used to estimate equation 3. As table 1 illustrated many parliaments do not provide the necessary information for all parliamentary votes. Provided that some random process leads to request for published roll-calls, using this subset of data would again cause no problems for estimating equation 3 .

Given that the occurrence of a roll-call vote whose results will be published is not random, we may suspect that there are some systematic elements which help us explain its occurrence $\left(r_{i}=1\right.$ if roll-call occurs, $r_{i}=0$ else):

$$
\begin{gathered}
r_{i}=\left\{\begin{array}{l}
1 \text { if } r_{i}^{*}>0 \\
0 \text { if } r_{i}^{*} \leq 0
\end{array}\right. \\
R^{*}=V \beta_{V}+\theta
\end{gathered}
$$

with $V$ comprising characteristics of the votes in question. Assuming that equation 5 accurately describes the occurrence of roll calls, we know that

$$
y_{i}=\left\{\begin{array}{l}
y_{o b s} \text { if } r_{i}^{*}>0 \\
. \text { if } r_{i}^{*} \leq 0
\end{array}\right.
$$

Hence we can estimate equation 3 only for observations for which $r_{i}^{*}>0$. At least since the seminal work by Heckman (1976) it is well known that in presence of data characterized by equations 3 and 5 , estimating the former equation without considering the latter may result in biased estimates. More precisely, Heckman (1976) demonstrated that as long as $\sigma_{\epsilon, \theta} \neq 0$ estimating equation 3 on the observed data suffers from a problem closely related to omitted variable bias.

Returning to the examples cited above, there is ample evidence that equations 3 and 5 almost by definition will exclude variables being relegated into the respective error terms. Most likely (and I provide evidence for this below), the two error terms contain in part similar elements. Taking the work by Gabel and Carrubba (2004) and Carrubba, Gabel, Murrah, Clough, Montegomery and Schambach (forthcoming) again as example, the fact that bills from particular 
committees of the European parliament are never subject to roll call votes (at least for the period they consider) is certainly also related to the likely decisions of the members of the European parliament. Similarly, factors influencing a request for a roll-call vote but not included in equation 5 (e.g., subjective importance of a bill) are likely also to affect the voting decisions of members of the European parliament (i.e., equation 3). Hence, the assumption $\sigma_{\epsilon, \theta} \neq 0$ is very unlikely to hold.

Stating the problem in the terms used above also suggests possible solutions. Quite clearly models of selection bias (e.g., Heckman, 1976; Maddala, 1983; Achen, 1986; Dubin and Rivers, 1990; Breen, 1996) allow us to address the problems in estimating equation 3 quite directly. On the practical level, however, equation 3 is often not our prime interest, at least to determine the dimensionality of a policy space or to assess the cohesion of party groups.

For the former problem, it is obvious that in order to determine $X$ and $\beta_{X}$ without possible selection bias we would need a full set of observations on $Y$. This full set of observations could be generated by estimating equations 3 and 5 on the observed portion of the data (i.e., most likely $W$ for all votes and $Z$ for all legislators, while omitting $X$ ) and use these estimates to make predictions on the portion of $Y$ which remains unobserved. This imputed data could then be used to determine the dimensionality of the policy space employing the various techniques discussed, for instance, by Poole (2005). Obviously, this imputation step would have to be carried out several times, given our uncertainty in the imputation stage. ${ }^{14}$ Even more attractive would obviously be an integrated approach, i.e., estimating the dimensionality of the policy space while simultaneously addressing the selection bias issue. Most likely, such an endeavor would only be feasible in a Bayesian framework. ${ }^{15}$

For the second practical problem, namely to assess party cohesion while taking into account problems of selection bias, equations 3 and 5 can be more directly employed. When studying party cohesion, for instance by employing the wellknown Rice-index (Rice, 1925) it can be noted that under the assumption of

\footnotetext{
${ }^{14}$ An alternative would obviously be to impute the whole datasets employing Amelia (e.g. Honaker, Joseph, King, Scheve and Singh, 1998).

${ }^{15}$ Interestingly, a comparison of the policy space generated by all recorded votes and those published in the Swiss parliament failed to highlight any significant differences (see Hug and Schulz, 2006 forthcoming). This, however, is likely due to the fact that for all bills at least one roll call vote is recorded, given the specific rules employed in this legislature.
} 
binary votes having this index for party groups as dependent variable simply implies an aggregation of equation 3 over the $j$ party groups: ${ }^{16}$

$$
\bar{Y}^{j}=\bar{X}^{j} \beta_{X}+\bar{W}^{j} \beta_{W}+\bar{Z}^{j} \beta_{Z}+\bar{\epsilon}^{j}
$$

Multiplying both sides by 2 and subtracting 1 yields on the left-hand side simply the Rice-index. ${ }^{17}$ Specifying our empirical model in this fashion also highlights two issues of importance. First of all, assuming that equation 3 is the correct empirical model, estimating equation 7 has to take account of the fact that we are in the presence of heteroskedasticity due to the aggregation of the individual votes. Second, we also need to be aware, that due to the aggregation several explanatory variables (namely $X, W$ and $Z$ ) only vary across party groups or across votes. Hence, the variance-covariance matrix is most likely a little bit more complicated than what is normally assumed in a classical linear regression model. ${ }^{18}$

Using data from two full and one partial legislatures ${ }^{19}$ of the Swiss lower house (45th: 1995-1999, 46th: 1999-2003, 47th: 2003-2004) I estimated equation 7 as transformed to have the Rice-index as dependent variable in conjunction with equations 4 and 5 as a simple Heckman selection model. ${ }^{20}$ In equation 5 I used as variables to explain the occurrence of a roll-call the type of vote. ${ }^{21}$ In equation $7 \mathrm{I}$ used as unique independent variables dichotomous indicators for all party groups except the liberal one. To account for possible contamination across party groups in a single vote, I allowed for clustered errors per vote.

In table 4 I report the results of the first stage selection equation which I estimated in a probit model. Given that some categories of votes either always or

\footnotetext{
${ }^{16}$ Here I obviously gloss over the fact that I have not yet specified how equation 3 relates to equation 2. Normally this link would be provided by a probit or logit function, for what follows, the assumption is however that it is a linear relationship. This is only done for presentational purposes.

${ }^{17}$ This works only, however, if the dependent variable $Y$ in equation 3 corresponds to the majority vote of each party group. This also requires the appropriate changes in signs of the independent variables.

${ }^{18}$ For one, it seems prudent to allow for clustered errors across individual votes.

${ }^{19}$ I report here the results of the partial legislature only for the sake of completeness. In 2003 the parliament adopted new standing orders, which made all voting records publicly available, even those not published in the parliamentary record. Hence, this change in the standing order has to be taken into account when comparing the results that I present below.

${ }^{20}$ Given the independent variables I employ their transformation is not required (see below).

${ }^{21}$ In the appendix I provide a table of the various categories coded in the dataset I used.
} 
Table 4: Explaining request for roll call vote (excluding automatically published votes)

\begin{tabular}{|c|c|c|c|}
\hline & $\begin{array}{c}\text { 45th legislature } \\
1995-1999\end{array}$ & $\begin{array}{c}\text { 46th legislature } \\
1999-2003\end{array}$ & $\begin{array}{c}\text { 47th legislature } \\
2003-2004\end{array}$ \\
\hline category of vote & $\begin{array}{c}\mathrm{b} \\
\text { (s.e.) }\end{array}$ & $\begin{array}{c}\mathrm{b} \\
\text { (s.e.) }\end{array}$ & $\begin{array}{c}\mathrm{b} \\
\text { (s.e.) }\end{array}$ \\
\hline Fiscal restraint & $\begin{array}{l}-0.374 \\
(0.178)\end{array}$ & $\begin{array}{l}-0.471 \\
(0.152)\end{array}$ & \\
\hline Opening vote & $\begin{array}{c}0.657 \\
(0.173)\end{array}$ & $\begin{array}{c}0.526 \\
(0.142)\end{array}$ & $\begin{array}{c}0.462 \\
(0.302)\end{array}$ \\
\hline Motion & $\begin{array}{l}-0.067 \\
(0.167)\end{array}$ & $\begin{array}{l}-0.115 \\
(0.102)\end{array}$ & $\begin{array}{l}-0.173 \\
(0.306)\end{array}$ \\
\hline Procedural vote & $\begin{array}{l}-0.564 \\
(0.247)\end{array}$ & $\begin{array}{l}-0.163 \\
(0.183)\end{array}$ & $\begin{array}{l}-0.354 \\
(0.490)\end{array}$ \\
\hline Parlamentay initiative & $\begin{array}{c}0.582 \\
(0.138)\end{array}$ & $\begin{array}{c}0.381 \\
(0.127)\end{array}$ & $\begin{array}{c}0.617 \\
(0.204)\end{array}$ \\
\hline Postulat & $\begin{array}{l}-0.600 \\
(0.342)\end{array}$ & $\begin{array}{l}-0.802 \\
(0.213)\end{array}$ & $\begin{array}{l}-0.149 \\
(0.376)\end{array}$ \\
\hline Motion to recommit to committee & $\begin{array}{c}0.576 \\
(0.158)\end{array}$ & $\begin{array}{c}0.257 \\
(0.251)\end{array}$ & $\begin{array}{c}0.446 \\
(0.275)\end{array}$ \\
\hline Cantonal initiative & $\begin{array}{c}0.563 \\
(0.531)\end{array}$ & $\begin{array}{l}-0.429 \\
(0.384)\end{array}$ & \\
\hline constant & $\begin{array}{l}-0.993 \\
(0.037)\end{array}$ & $\begin{array}{l}-0.852 \\
(0.034)\end{array}$ & $\begin{array}{l}-1.210 \\
(0.059) \\
\end{array}$ \\
\hline $\begin{array}{l}\text { Log likelihood } \\
N\end{array}$ & $\begin{array}{c}-971.009 \\
2192\end{array}$ & $\begin{array}{c}-1221.985 \\
2552\end{array}$ & $\begin{array}{c}-352.484 \\
959\end{array}$ \\
\hline $\mathrm{LR} c h i^{2}$ & 60.890 & 58.230 & 14.260 \\
\hline Prob $>c h i^{2}$ & 0.000 & 0.000 & 0.027 \\
\hline
\end{tabular}

never led to roll call votes, I had to drop some vote types and the corresponding observations. This obviously also concerned all the votes that are automatically published, which I eliminated from the present analysis and all subsequent ones. ${ }^{22}$ What the results clearly illustrate, however, is the fact that there are some systematic elements in the decision to call for a roll call vote. The most systematic effects appear for parliamentary initiatives and motions to recommit bills to committees. Compared to the base category of the probit analysis, namely votes on legislative details (i.e., articles of bills etc.), both of these votes are much more likely to be roll calls. And this difference appears in both full legislatures and the partial one I consider. Some other types of votes also seem to be systematically

\footnotetext{
${ }^{22}$ Obviously, given the rather important differences in cohesion scores between automatically published votes and all others, I make my task of correcting estimates of cohesion scores more difficult.
} 
more (or less) likely to be subject to roll calls, but not so in all legislatures.

The information obtained from these probit estimates allows us to determine the so-called Mills-ratio, which Heckman (1976) has demonstrated is an omitted variable in equation 7 if there is selectivity. Hence, I estimated a series of simple linear regressions in which the Rice-index of party groups appeared as dependent variable and the Mills-ratio as one of the independent variables. ${ }^{23}$ The other independent variables were either only a constant if I used the Rice-indices of one party group as dependent variable or a set of dummies for the party groups. Estimating these regressions for the three legislatures either for all party groups together or individual party groups allows me to calculate predictions for the Rice-indices under two assumptions. ${ }^{24}$ Under the first assumption the selection effect is the same for all party groups, while under the second one this effect may differ.

Table 5 reports these two sets of predicted Rice-indices (columns 2 and 3) together with Rice-indices for the requested roll call votes (column 1) and for the whole set of not automatically published votes (column 4). In the 45th legislature we note that the predicted Rice-indices are closer to those based on all votes for four party groups if we assume that the selection effect is the same for all groups. More precisely, the values in column 2 are closer to those in column 4 than the Rice-indices calculated on the basis of only the requested roll call votes (column 1). This is the case for the Freedom party, the Greens the Social-democrats and the People's party. For the other party groups the corrections go in the wrong direction. If we consider that the effect of the Mills-ratio may be party specific (column 3), the predicted values are closer to the true values for the Liberals and the People's party. Hence it seems, that the selection effects seem to work in the same direction for most of the party groups considered in the 45th legislature.

\footnotetext{
${ }^{23}$ This procedure corresponds to the two-step estimator proposed by Heckman (1976) and discussed in detail by Achen (1986). I also estimated all models with a full-information maximumlikelihood model and obtained largely identical results.

${ }^{24} \mathrm{I}$ refrain from reporting the results of the linear regressions, since table 5 indirectly reports the estimated coefficients. Given the preliminary nature of the underlying theoretical model I also refrain from reporting uncertainty estimates for these predictions.
} 
Table 5: Rice-index (excluding automatically published votes)

\begin{tabular}{|c|c|c|c|c|}
\hline \multirow[t]{2}{*}{ party group } & $\begin{array}{l}\text { all published } \\
\text { votes } \\
\text { Rice-index } \\
\text { (n) }\end{array}$ & $\begin{array}{c}\text { predicted } \\
\text { (Heckman: all) } \\
\text { Rice-index } \\
\text { (n) }\end{array}$ & $\begin{array}{c}\text { predicted } \\
\text { (Heckman: by party) } \\
\text { Rice-index } \\
\text { (n) }\end{array}$ & $\begin{array}{l}\text { all votes } \\
\text { Rice-index } \\
\text { (n) }\end{array}$ \\
\hline & \multicolumn{4}{|c|}{ 45th Legislature (1995-1999) } \\
\hline Christian-democracts & $\begin{array}{l}0.701 \\
(372)\end{array}$ & $\begin{array}{c}0.700 \\
(2229)\end{array}$ & $\begin{array}{c}0.697 \\
(2229)\end{array}$ & $\begin{array}{c}0.751 \\
(2227)\end{array}$ \\
\hline Freedom party & $\begin{array}{l}0.952 \\
(357)\end{array}$ & $\begin{array}{l}0.951 \\
(2229)\end{array}$ & $\begin{array}{l}0.952 \\
(2229)\end{array}$ & $\begin{array}{l}0.947 \\
(2135)\end{array}$ \\
\hline Greens & $\begin{array}{l}0.936 \\
(374)\end{array}$ & $\begin{array}{l}0.935 \\
(2229)\end{array}$ & $\begin{array}{l}0.937 \\
(2229)\end{array}$ & $\begin{array}{l}0.935 \\
(2228)\end{array}$ \\
\hline Liberals & $\begin{array}{l}0.866 \\
(373)\end{array}$ & $\begin{array}{l}0.865 \\
(2229)\end{array}$ & $\begin{array}{l}0.866 \\
(2229)\end{array}$ & $\begin{array}{l}0.890 \\
(2217)\end{array}$ \\
\hline Radicals & $\begin{array}{l}0.699 \\
(374)\end{array}$ & $\begin{array}{l}0.697 \\
(2229)\end{array}$ & $\begin{array}{l}0.693 \\
(2229)\end{array}$ & $\begin{array}{l}0.764 \\
(2229)\end{array}$ \\
\hline Social-democrats & $\begin{array}{l}0.966 \\
(374)\end{array}$ & $\begin{array}{l}0.965 \\
(2229)\end{array}$ & $\begin{array}{l}0.966 \\
(2229)\end{array}$ & $\begin{array}{l}0.939 \\
(2229)\end{array}$ \\
\hline People's party & $\begin{array}{l}0.866 \\
(374)\end{array}$ & $\begin{array}{c}0.864 \\
(2229)\end{array}$ & $\begin{array}{l}0.865 \\
(2229)\end{array}$ & $\begin{array}{l}0.858 \\
(2229)\end{array}$ \\
\hline \multicolumn{5}{|c|}{ 46th Legislature (1999-2003) } \\
\hline Christian-democracts & $\begin{array}{l}0.675 \\
(588)\end{array}$ & $\begin{array}{c}0.676 \\
(2670)\end{array}$ & $\begin{array}{c}0.675 \\
(2670)\end{array}$ & $\begin{array}{c}0.739 \\
(2668)\end{array}$ \\
\hline Greens & $\begin{array}{l}0.979 \\
(584)\end{array}$ & $\begin{array}{l}0.980 \\
(2670)\end{array}$ & $\begin{array}{l}0.980 \\
(2670)\end{array}$ & $\begin{array}{l}0.966 \\
(2659)\end{array}$ \\
\hline Liberals & $\begin{array}{l}0.911 \\
(586)\end{array}$ & $\begin{array}{l}0.912 \\
(2670)\end{array}$ & $\begin{array}{l}0.914 \\
(2670)\end{array}$ & $\begin{array}{l}0.916 \\
(2648)\end{array}$ \\
\hline Radicals & $\begin{array}{l}0.763 \\
(588)\end{array}$ & $\begin{array}{l}0.763 \\
(2670)\end{array}$ & $\begin{array}{l}0.763 \\
(2670)\end{array}$ & $\begin{array}{l}0.800 \\
(2669)\end{array}$ \\
\hline Social-democrats & $\begin{array}{l}0.958 \\
(587)\end{array}$ & $\begin{array}{l}0.958 \\
(2670)\end{array}$ & $\begin{array}{l}0.954 \\
(2670)\end{array}$ & $\begin{array}{l}0.944 \\
(2667)\end{array}$ \\
\hline People's party & $\begin{array}{l}0.861 \\
(588)\end{array}$ & $\begin{array}{c}0.862 \\
(2670)\end{array}$ & $\begin{array}{l}0.865 \\
(2670)\end{array}$ & $\begin{array}{l}0.876 \\
(2670)\end{array}$ \\
\hline \multicolumn{5}{|c|}{ 47th Legislature (2003-2004) } \\
\hline Christian-democracts & $\begin{array}{l}0.764 \\
(131)\end{array}$ & $\begin{array}{l}0.762 \\
(980)\end{array}$ & $\begin{array}{l}0.777 \\
(980)\end{array}$ & $\begin{array}{l}0.789 \\
(979)\end{array}$ \\
\hline Greens & $\begin{array}{l}0.971 \\
(132)\end{array}$ & $\begin{array}{l}0.970 \\
(980)\end{array}$ & $\begin{array}{l}0.972 \\
(980)\end{array}$ & $\begin{array}{l}0.973 \\
(972)\end{array}$ \\
\hline Radicals & $\begin{array}{l}0.726 \\
(132)\end{array}$ & $\begin{array}{l}0.725 \\
(980)\end{array}$ & $\begin{array}{l}0.716 \\
(980)\end{array}$ & $\begin{array}{l}0.813 \\
(979)\end{array}$ \\
\hline Social-democrats & $\begin{array}{l}0.938 \\
(132)\end{array}$ & $\begin{array}{l}0.937 \\
(980)\end{array}$ & $\begin{array}{l}0.933 \\
(980)\end{array}$ & $\begin{array}{l}0.949 \\
(973)\end{array}$ \\
\hline People's party & $\begin{array}{l}0.866 \\
(132)\end{array}$ & $\begin{array}{l}0.865 \\
(980)\end{array}$ & $\begin{array}{l}0.861 \\
(980)\end{array}$ & $\begin{array}{l}0.904 \\
(980)\end{array}$ \\
\hline
\end{tabular}


Turning to the 46th legislature we find again four predicted values to approximate the true values better than the Rice-indices based on the requested roll call votes assuming identical selection effects. In this legislature these corrections work for the Christian-democrats, the Liberals, the Radicals and the People's party. If we allow for party group specific effects for the Mills-ratio we find also four corrections which go in the right direction, namely the ones for the Christian-democrats, the Liberals, the Socialists and the People's party. Interestingly enough in this case, with the exception of the Christian-democrats, the corrections are substantially better if we assume party-group specific effects of the Mills-ratio.

Finally, if we turn to the partial data for the 47th legislature, which also saw a change in the way in which votes are publicly available, we find weaker results. More precisely, under the assumption that the Mills-ratio affects the Rice-index in the same way for all parties, we find that all our predictions correct the Riceindices in the wrong direction. If we allow for party-group specific effects, our corrections only work in two cases, namely for the Christian-democrats and the Greens. ${ }^{25}$

Given the sparseness of the empirical model estimated, the corrections I present in table 5 are quite encouraging. For around half the Rice-indices the corrections based on the very simple Heckman model provide better estimates than the Rice-indices calculated on the basis of the requested roll-call votes. The fact that the corrections calculated under the assumption of a selection effect common to all party groups suggest that a more precise theoretical model may still improve the predictions based on the Heckman model. Especially if it could be determined which party group requests a roll-call vote, much more precise estimates and corrections could be proposed. Obviously an even harder test would be to estimate this model with an incidental truncation model. Hug (2003) shows, however, that quite a strong correlation between the error terms is required to make this model a valuable alternative. The results from the Heckman model used here suggest that this is unfortunately not the case. Again, this is likely to be due to the sparseness of the empirical model for the selection equation.

\footnotetext{
${ }^{25}$ The Liberals fail to appear in this table for the last legislature, since they joined the party group of the Radicals.
} 


\section{Conclusion}

Roll call votes are increasingly used in comparative studies of various aspects of legislatures. Such comparative work has, however, to be attentive to the fact that roll call votes occur under various institutional provisions. Provided that the institutional provisions restrict in some ways roll call votes or make them public only under particular circumstances, we need to worry about possible selection biases.

While Gabel and Carrubba (2004) and Carrubba, Gabel, Murrah, Clough, Montegomery and Schambach (forthcoming) were able to demonstrate that roll call votes in the European parliament differ systematically along several dimensions from the remaining votes, I attempted to demonstrate the problems of selection bias by employing a unique data source. Relying on a dataset comprising information on all votes by MPs in the Swiss lower house for two legislative periods, I am able to demonstrate that for most parties requested roll calls and automatically published votes differ systematically in terms of party cohesion from the remaining votes that are not published. A simple selection model also shows that these biases may be corrected for, provided we have a reasonably well-specified empirical model for the selection equation.

Taken together with the theoretical argument concerning the requests for roll calls in the European parliament by Carrubba and Gabel (1999), this clearly suggests that selection effects are very likely in roll calls, provided not all votes are recorded and published. Hence, our research effort should address much more directly these issues of selection biases in roll call studies, especially in those with a comparative dimension. Neglecting these issues is likely to lead to biased inferences over important aspects of the legislatures studied. 


\section{Appendix}

Table 6 reports detailed information on the institutional provisions for the recording of votes in the parliamentary chambers in 92 countries that appears in a summarized fashion in table 1 of the main text. In table 7 I report the distribution of votes over the various categories of all votes.

Table 6: Provisions for roll calls in national parliaments

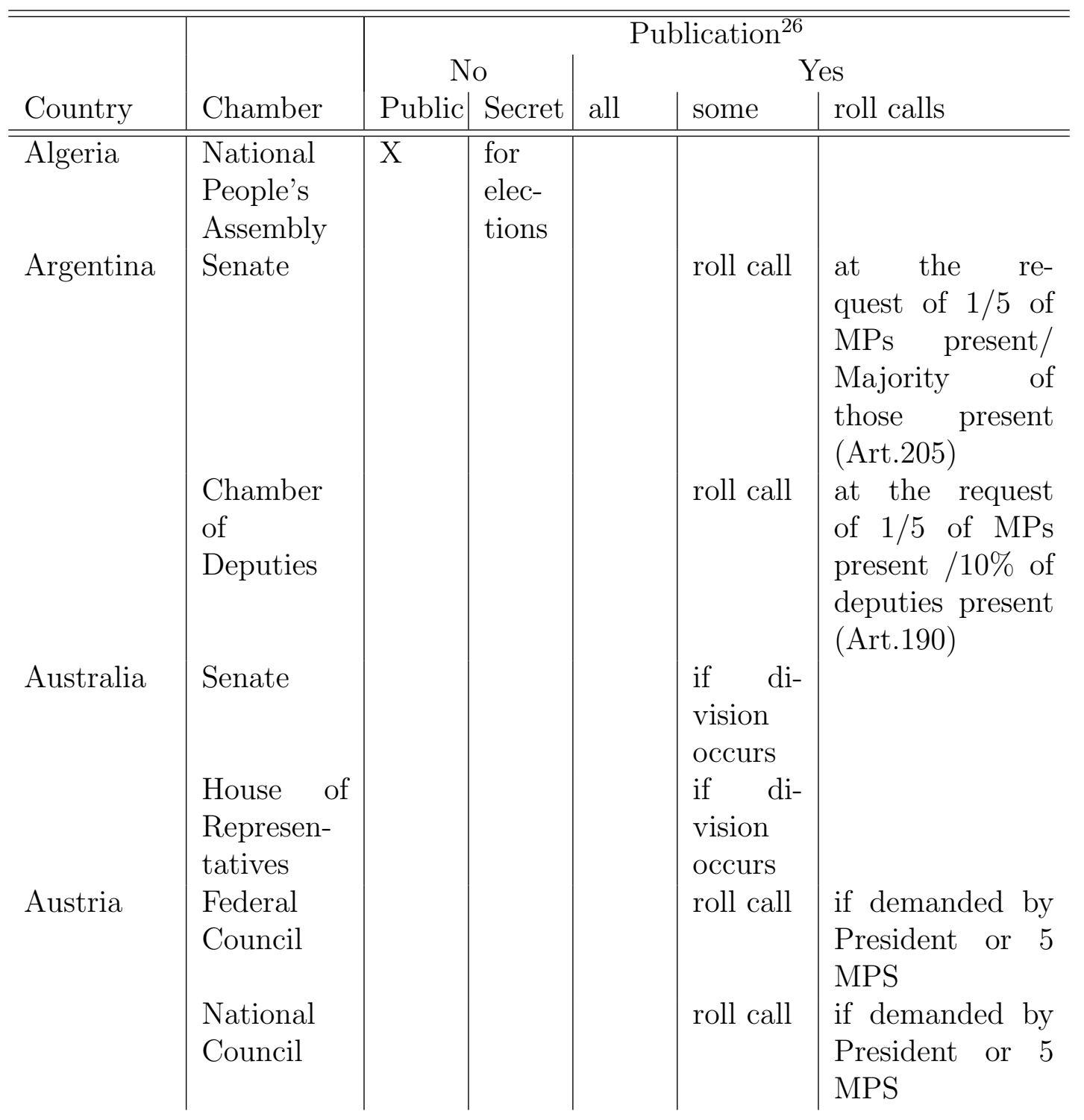




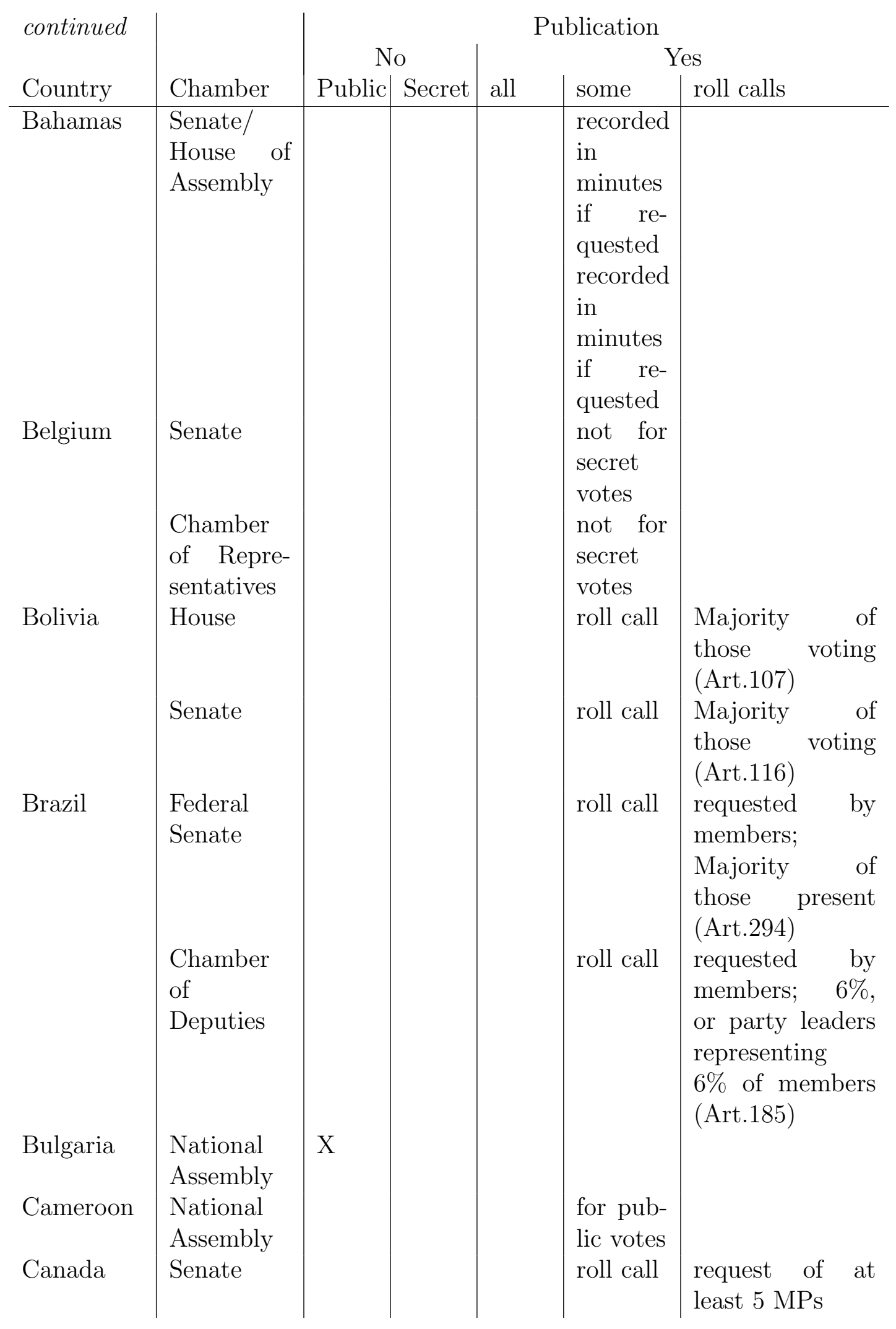




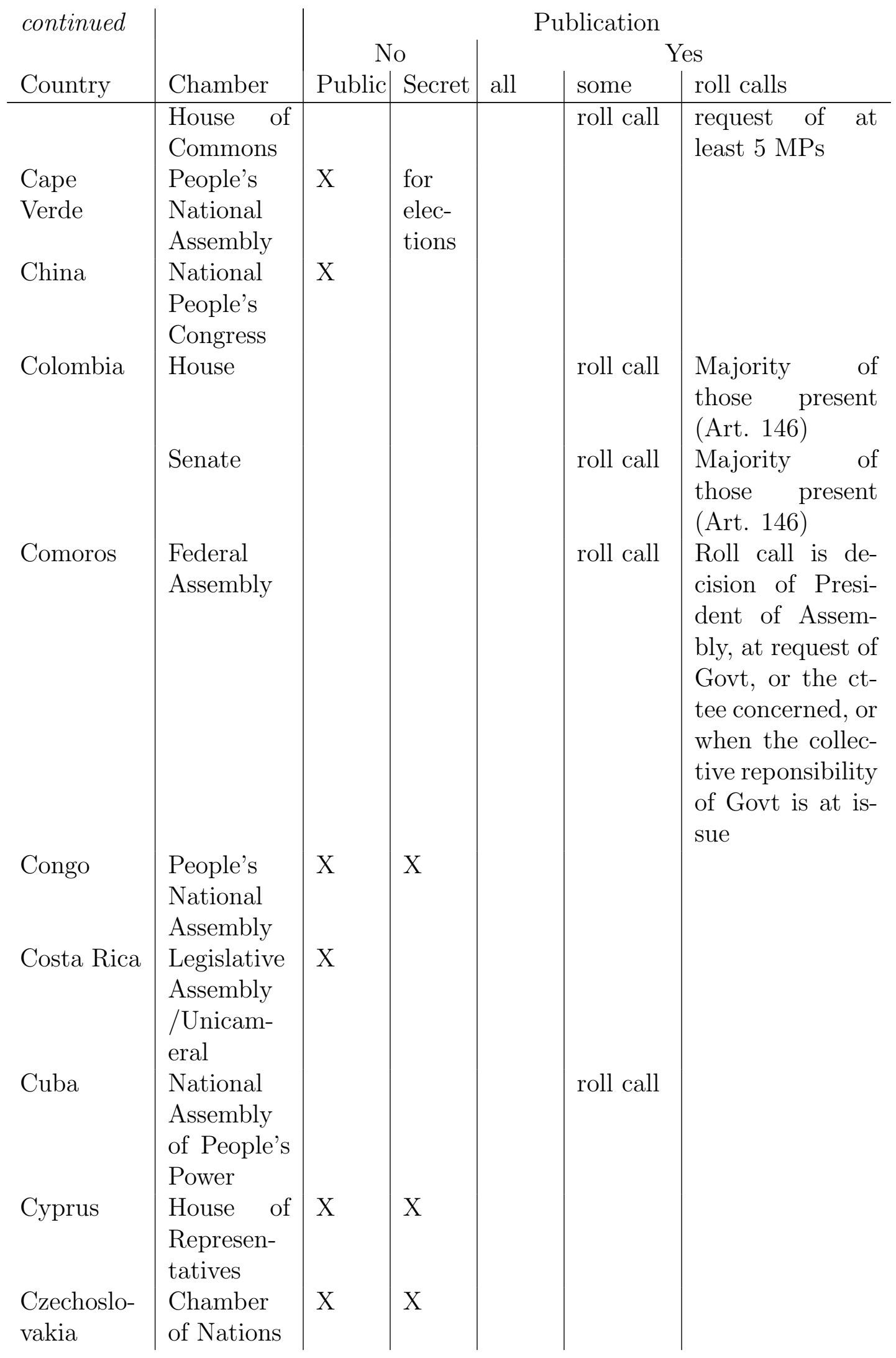




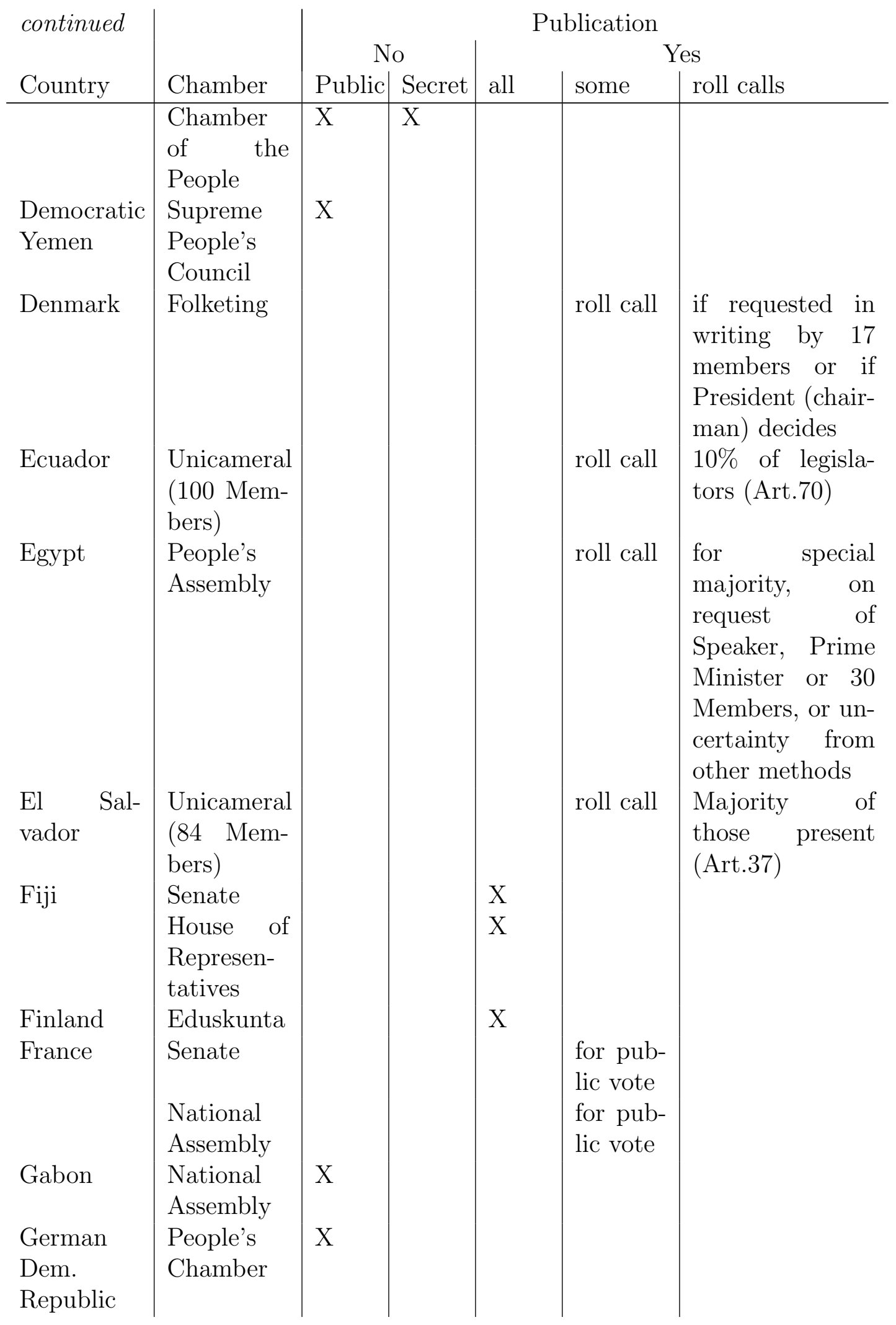




\begin{tabular}{|c|c|c|c|c|c|c|}
\hline \multirow{3}{*}{$\begin{array}{l}\text { continued } \\
\text { Country }\end{array}$} & \multirow[b]{3}{*}{ Chamber } & \multicolumn{5}{|c|}{ Publication } \\
\hline & & $\mathrm{N}$ & & & & es \\
\hline & & Public & Secret & all & some & roll calls \\
\hline Germany & $\begin{array}{l}\text { Federal } \\
\text { Council }\end{array}$ & & & & roll call & $\begin{array}{l}\text { if requested by } \\
\text { a State and } \\
\text { for election of } \\
\text { Council Presi- } \\
\text { dent / recorded } \\
\text { vote only if it } \\
\text { is demanded } \\
\text { by at least five } \\
\text { per cent of the } \\
\text { House }\end{array}$ \\
\hline & $\begin{array}{l}\text { Federal } \\
\text { Diet }\end{array}$ & & & & & \\
\hline Greece & $\begin{array}{l}\text { Chamber } \\
\text { of } \\
\text { Deputies }\end{array}$ & & & & roll call & $\begin{array}{l}\text { recorded vote } \\
\text { only if it is } \\
\text { demanded by } \\
\text { at least five } \\
\text { per cent of the } \\
\text { House }\end{array}$ \\
\hline Guatemala & $\begin{array}{l}\text { Unicameral } \\
\text { (140 Mem- } \\
\text { bers) }\end{array}$ & & & & roll call & $\begin{array}{l}6 \quad \text { legislators } \\
\text { (Art.95) }\end{array}$ \\
\hline Hungary & $\begin{array}{l}\text { National } \\
\text { Assembly }\end{array}$ & & & $\mathrm{X}$ & & \\
\hline Iceland & & & & & roll call & $\begin{array}{lr}\text { individual } & \mathrm{MP}, \\
\text { chairman, } & \text { gov- } \\
\text { ernment } & \text { or } \\
\text { government } & \\
\text { minister } & \end{array}$ \\
\hline India & $\begin{array}{l}\text { Council of } \\
\text { States } \\
\text { House of } \\
\text { the People }\end{array}$ & & & $\begin{array}{l}\mathrm{X} \\
\mathrm{X}\end{array}$ & & \\
\hline Indonesia & $\begin{array}{l}\text { House of } \\
\text { Represen- } \\
\text { tatives }\end{array}$ & $\mathrm{X}$ & $\mathrm{X}$ & & & \\
\hline Ireland & $\begin{array}{l}\text { Senate } \\
\text { Dail }\end{array}$ & & & $\begin{array}{l}X \\
X\end{array}$ & & \\
\hline Israel & $\begin{array}{l}\text { The Knes- } \\
\text { set }\end{array}$ & & & & roll call & $\begin{array}{l}\text { if requested by } \\
\text { at least } 20 \mathrm{Mps}\end{array}$ \\
\hline
\end{tabular}




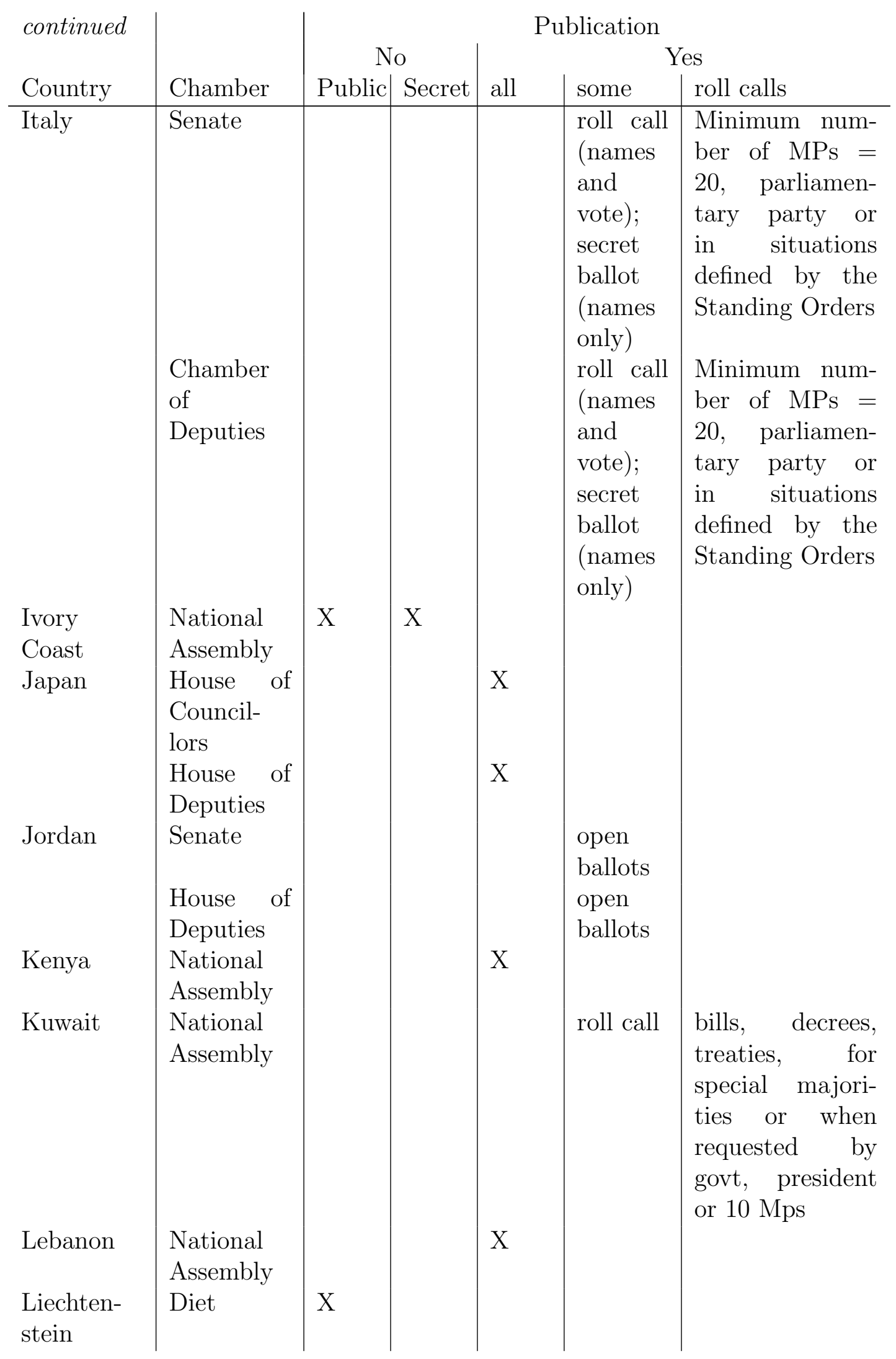




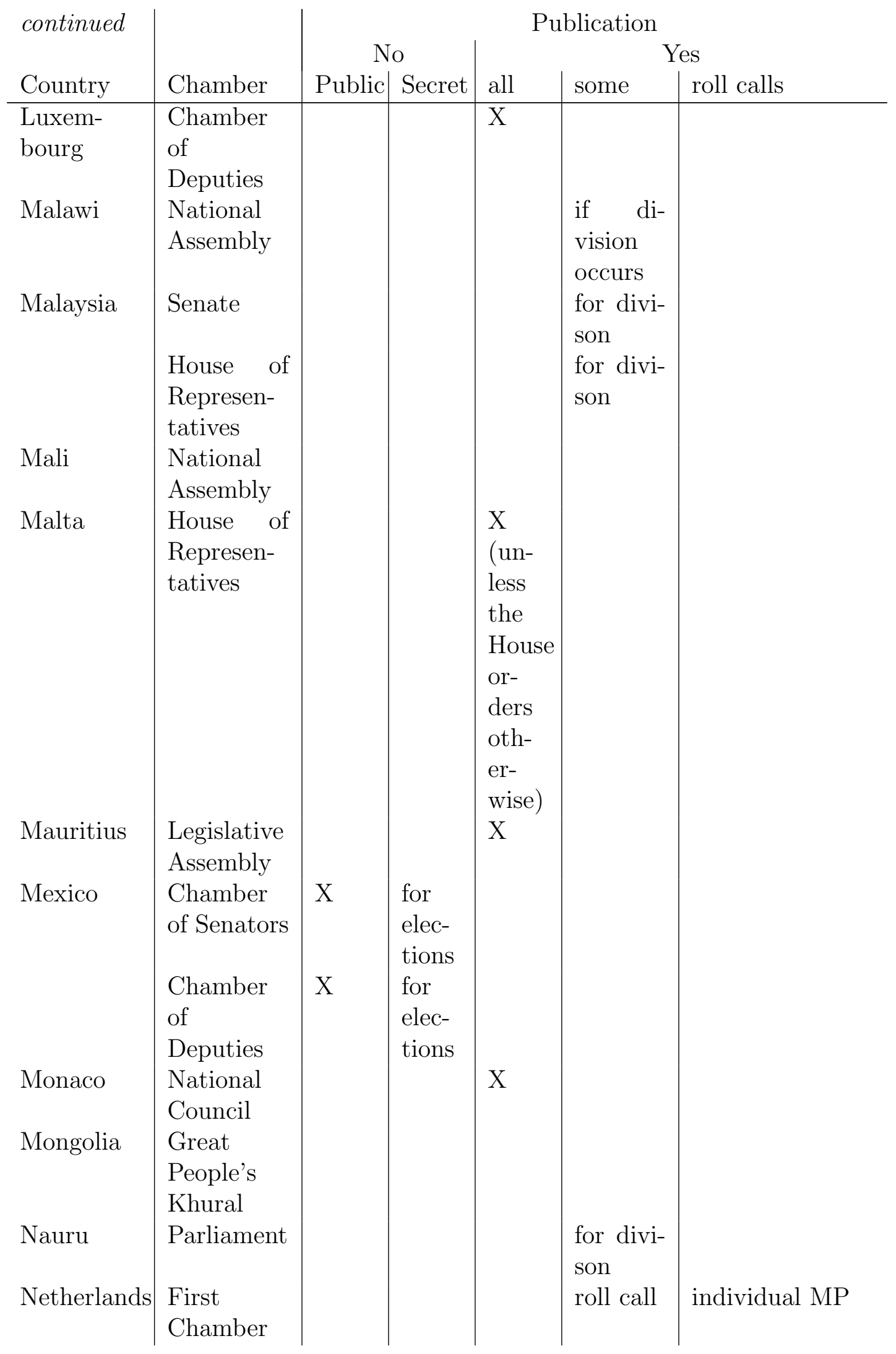




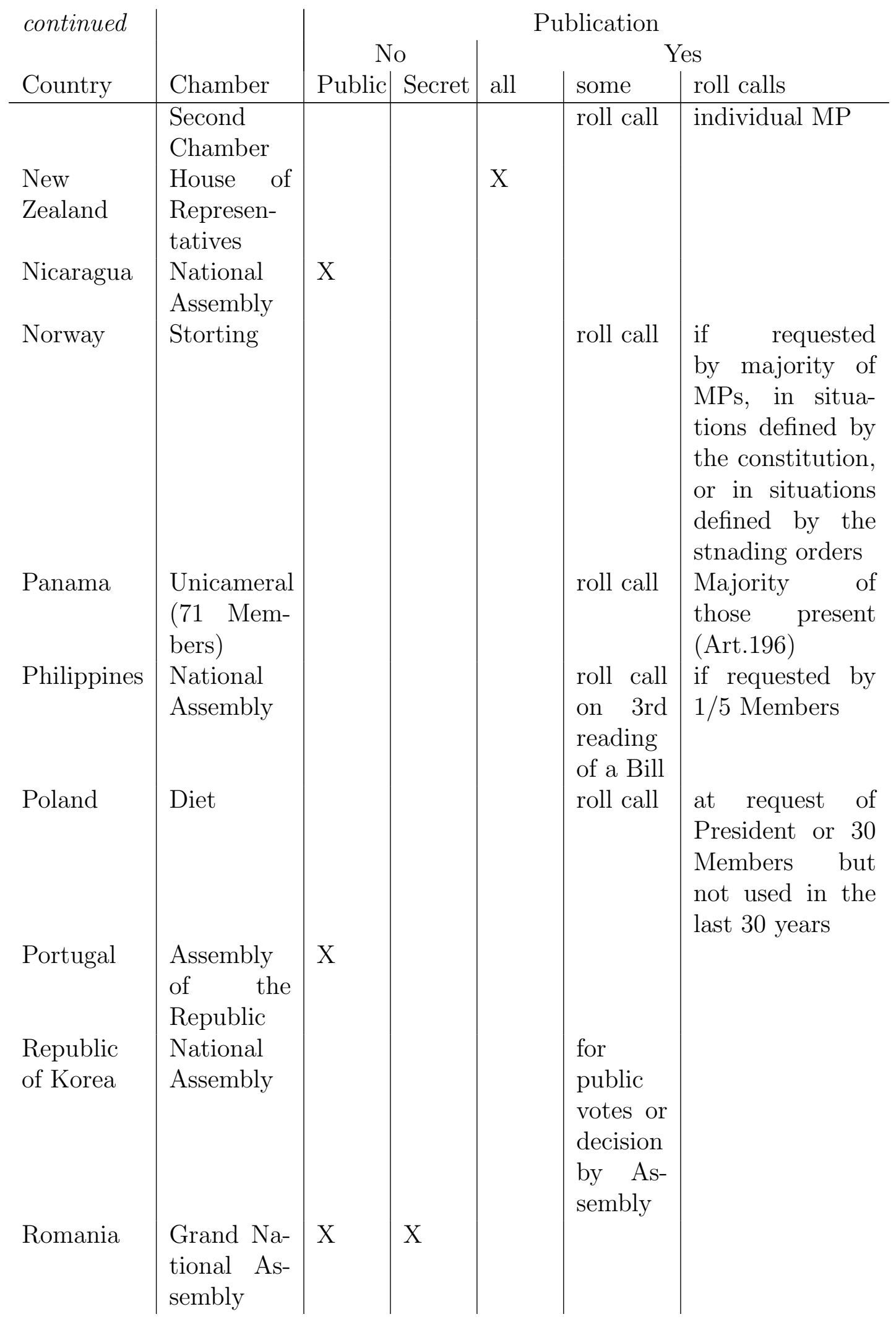




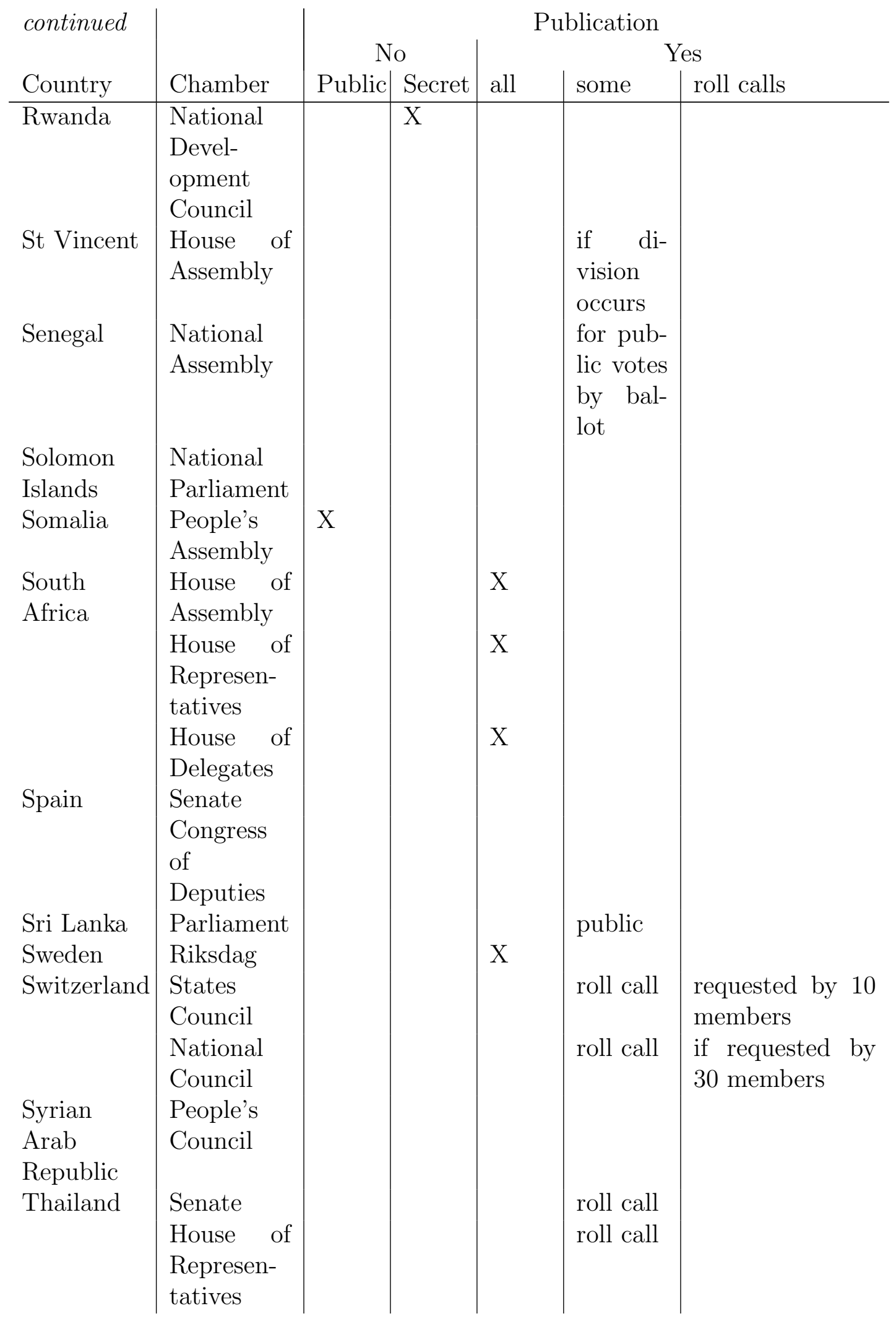




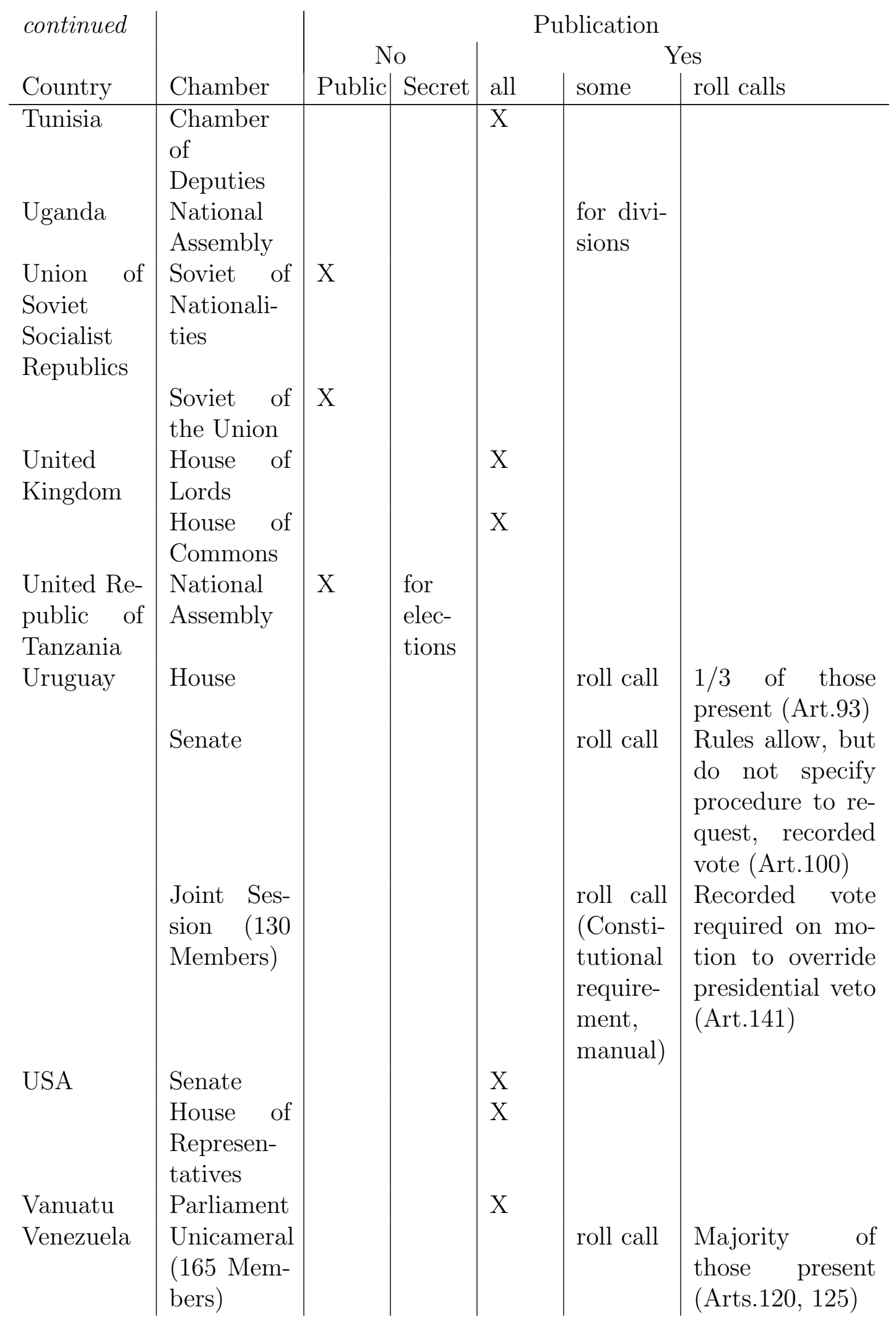




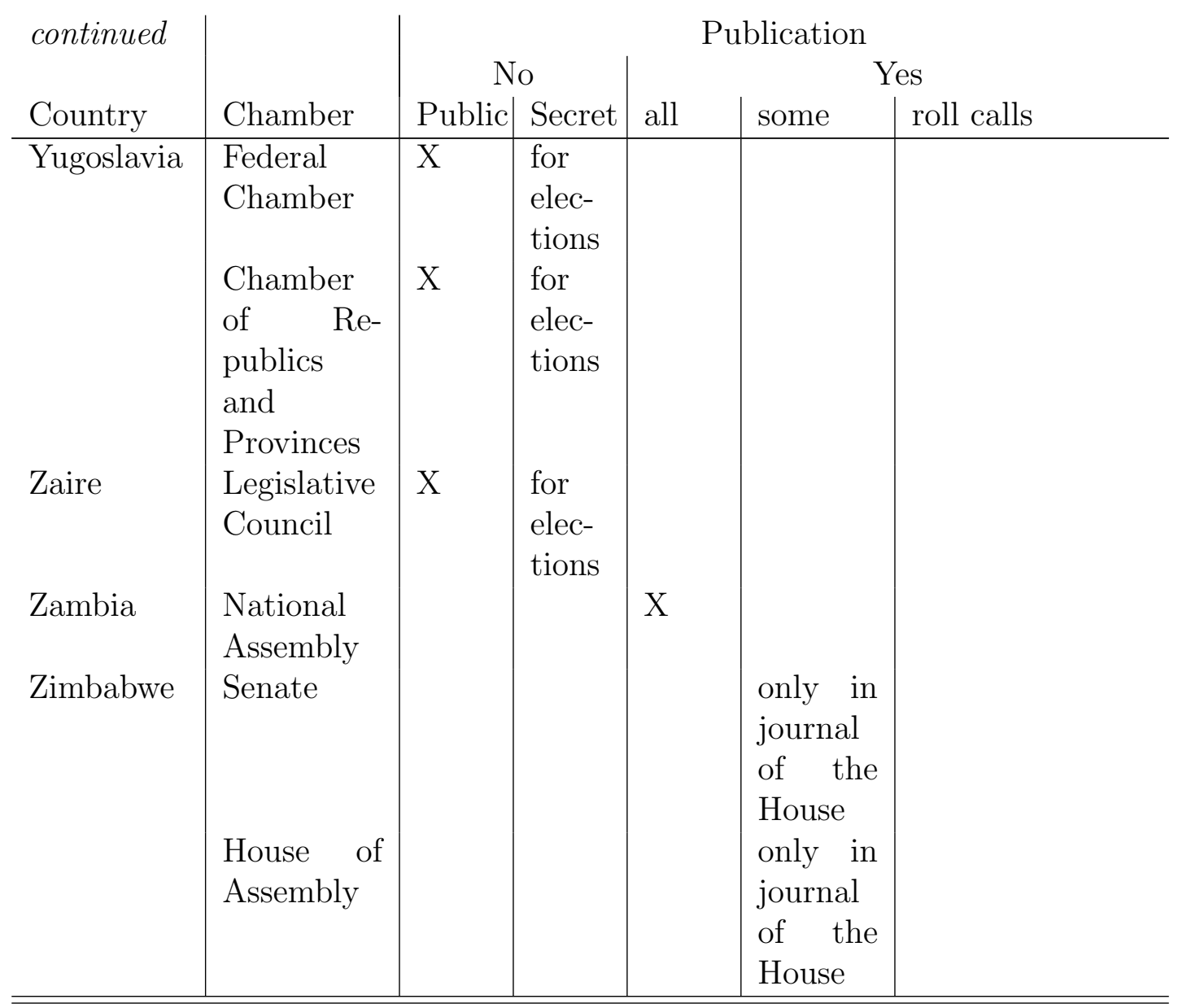


Table 7: Types of votes in 45th, 46th and 47th (partial) legislatures

\begin{tabular}{|c|c|c|c|c|}
\hline category of vote & $\begin{array}{c}\text { 45th legislature } \\
\text { 1995-1999 } \\
\% \\
\text { (n) }\end{array}$ & $\begin{array}{c}\text { 46th legislature } \\
1999-2003 \\
\% \\
\text { (n) }\end{array}$ & $\begin{array}{c}\text { 47th legislature } \\
2003-2004 \\
\% \\
\text { (n) }\end{array}$ & $\begin{array}{c}\text { total } \\
\% \\
\text { (n) }\end{array}$ \\
\hline Annulment & & $\begin{array}{l}0.2 \\
(6)\end{array}$ & & $\begin{array}{l}0.1 \\
(6)\end{array}$ \\
\hline Fiscal restraint & $\begin{array}{c}3.8 \\
(105)\end{array}$ & $\begin{array}{c}4.3 \\
(140)\end{array}$ & $\begin{array}{c}1.1 \\
(13)\end{array}$ & $\begin{array}{c}3.6 \\
(258)\end{array}$ \\
\hline Detailed discussion & $\begin{array}{c}59.7 \\
(1666)\end{array}$ & $\begin{array}{c}53.7 \\
(1751)\end{array}$ & $\begin{array}{c}69.1 \\
(784)\end{array}$ & $\begin{array}{c}58.5 \\
(4201)\end{array}$ \\
\hline Motion of discussion & $\begin{array}{c}1.1 \\
(31)\end{array}$ & $\begin{array}{l}0.2 \\
(8)\end{array}$ & & $\begin{array}{c}0.5 \\
(39)\end{array}$ \\
\hline Urgent measure & $\begin{array}{c}0.6 \\
(17)\end{array}$ & $\begin{array}{l}0.2 \\
(7)\end{array}$ & $\begin{array}{l}0.4 \\
(5)\end{array}$ & $\begin{array}{c}0.4 \\
(29)\end{array}$ \\
\hline Opening vote & $\begin{array}{l}2.0 \\
(57)\end{array}$ & $\begin{array}{c}2.6 \\
(86)\end{array}$ & $\begin{array}{l}1.9 \\
(22)\end{array}$ & $\begin{array}{c}2.3 \\
(165)\end{array}$ \\
\hline Declaration & & $\begin{array}{l}0.0 \\
(1)\end{array}$ & & $\begin{array}{l}0.0 \\
(1)\end{array}$ \\
\hline Total vote & $\begin{array}{c}13.1 \\
(366)\end{array}$ & $\begin{array}{c}14.4 \\
(468)\end{array}$ & $\begin{array}{l}8.6 \\
(97)\end{array}$ & $\begin{array}{c}13.0 \\
(931)\end{array}$ \\
\hline Motion & $\begin{array}{c}3.2 \\
(90)\end{array}$ & $\begin{array}{c}7.4 \\
(240)\end{array}$ & $\begin{array}{l}3.2 \\
(36)\end{array}$ & $\begin{array}{c}5.1 \\
(366)\end{array}$ \\
\hline Motion of order & $\begin{array}{c}2.4 \\
(67)\end{array}$ & $\begin{array}{c}2.2 \\
(71)\end{array}$ & $\begin{array}{c}1.5 \\
(17)\end{array}$ & $\begin{array}{c}2.2 \\
(155)\end{array}$ \\
\hline Parliamentary initiative & $\begin{array}{l}3.4 \\
(94)\end{array}$ & $\begin{array}{c}3.5 \\
(113)\end{array}$ & $\begin{array}{c}4.1 \\
(47)\end{array}$ & $\begin{array}{c}3.5 \\
(254)\end{array}$ \\
\hline Petition & $\begin{array}{l}0.1 \\
(2)\end{array}$ & $\begin{array}{l}0.2 \\
(7)\end{array}$ & $\begin{array}{l}0.3 \\
(3)\end{array}$ & $\begin{array}{c}0.2 \\
(12)\end{array}$ \\
\hline Postulat & $\begin{array}{c}1.3 \\
(36)\end{array}$ & $\begin{array}{c}3.1 \\
(102)\end{array}$ & $\begin{array}{c}2.0 \\
(23)\end{array}$ & $\begin{array}{c}2.2 \\
(161)\end{array}$ \\
\hline Motion for reconsideration & $\begin{array}{l}0.0 \\
(1)\end{array}$ & & & $\begin{array}{l}0.0 \\
(1)\end{array}$ \\
\hline Motion to committee & $\begin{array}{c}2.5 \\
(71)\end{array}$ & $\begin{array}{c}0.9 \\
(29)\end{array}$ & $\begin{array}{l}2.4 \\
(27)\end{array}$ & $\begin{array}{c}1.8 \\
(127)\end{array}$ \\
\hline Final vote & $\begin{array}{c}6.5 \\
(181)\end{array}$ & $\begin{array}{c}6.5 \\
(213)\end{array}$ & $\begin{array}{c}4.6 \\
(52)\end{array}$ & $\begin{array}{c}6.2 \\
(446)\end{array}$ \\
\hline Cantonal initiative & $\begin{array}{l}0.2 \\
(6) \\
\end{array}$ & $\begin{array}{c}0.6 \\
(20) \\
\end{array}$ & $\begin{array}{l}0.7 \\
(8)\end{array}$ & $\begin{array}{c}0.5 \\
(34) \\
\end{array}$ \\
\hline total & $(2790)$ & $(3262)$ & $(1134)$ & $(7186)$ \\
\hline
\end{tabular}




\section{References}

Achen, Christopher H. 1986. Statistical Analysis of Quasi-Experiments. Berkeley: University of California Press.

Amorim Neto, Octavio. 2002. Presidential Cabinets, Electoral Cycles, and Coalition Discipline in Brazil. In Legislative Politics in Latin America, ed. Scott Morgenstern and Benito Nacif. Cambridge: Cambridge University Press chapter 3 , pp. $48-78$.

Attina, Fulvio. 1990. "The Voting Behaviour of European Parliament Members and the Problem of the Europarties." European Journal of Political Research 18:557-579.

Bartels, Larry M. 1991. "Constituency Opinion and Congressional Policy Making: The Reagan Defense Buildup." American Political Science Review 85(2 June):457-474.

Bowler, Shaun, David M. Farrell and Richard S. Katz, eds. 1999. Party Discipline and Parliamentary Government. Columbus: Ohio State University Press.

Bowler, Shawn. 2000. Parties in Legislatures: Two Competing Explanations. In Parties Without Partisans, ed. Russell J Dalton and M.P. Wattenberg. Oxford: Oxford University Press pp. 157-179.

Breen, Richard. 1996. Regression Models: Censored, Sample Selected or Truncated Data. Thousand Oaks: Sage.

Brehm, John. 2000. "Alternative Corrections for Sample Truncation: Applications to the 1988 and 1990 Senate Election Studies." Political Analysis 8(2):183-199.

Brzinski, Joanne Bay. 1995. Political Group Cohesion in the European Parliament, 1989-1994. In The State of the European Union, Vol., ed. Carolyn Rhodes and Sonja Mazey. London:: Longman pp. 135-158.

Carey, John M. 2004. "Visible Votes: Recorded Voting and Legislative Accountability in Latin America." Unpublished paper, April 2004.

Carrubba, Clifford J. and Matthew Gabel. 1999. "Roll-Call Votes and Party Discipline in the European Parliament: Reconsidering MEP Voting Behavior." Paper prepared for presentation at the American Political Science Association Annual Meeting, September 2-5 Atlanta.

Carrubba, Clifford J., Matthew Gabel, Lacey Murrah, Ryan Clough, Elizabeth Montegomery and Rebecca Schambach. forthcoming. "Off the Record: Unrecorded Legislative Votes, Selection Bias, and Roll-Call Vote Analysis." British Journal of Political Science.

Clinton, Joshua D., Simon Jackman and Doug Rivers. 2004. "The Statistical Analysis of Roll Call Voting: A Unified Approach." American Political Science Review 98(2):355-370. 
Cox, Gary W. 1987. The Efficient Secret: The Cabinet and the Development of Political Parties in Victorian England. Cambridge: Cambridge University Press.

Cox, Gary W. and Mathew D. McCubbins. 2005. Setting the Agenda: Responsible Party Government in the U.S. House of Representatives. Cambridge: Cambridge University Press.

Depauw, Sam. 2003. "Government Party Discipline in Parliamentary Democracies: The Cases of Belgium, France and the United Kingdom in the 1990s." Journal of Legislative Studies 9(4):130-146.

Depauw, Sam and Shane Martin. 2005. "Legislative Party Discipline and Cohesion in Comparative Perspective." Paper presented at the ECPR Joint Sessions of Workshops, 14-19 April, Granada.

Desposato, Scott. 2006. "Yeas, Nays, and Silences: A Mixture Model of Party Cohesion." Paper presented at the annual meeting of the The Midwest Political Science Association, Palmer House Hilton, Chicago, Illinois.

Desposato, Scott W. 2003. "Comparing Group and Subgroup Cohesion Scores: A Nonparametric Method with an Application to Brazil." Political Analysis $11: 275-288$.

Desposato, Scott W. 2005. "Correcting for Bias in Rice Cohesion Scores." British Journal of Political Science 35(4):731-744.

Dubin, Jeffrey A. and Douglas Rivers. 1990. Selection Bias in Linear Regression, Logit and Probit Models. In Modern Methods of Data Analysis, ed. John Fox and Scott J. Long. Newbury Park: Sage pp. 410-442.

Gabel, Matthew J. and Clifford J. Carrubba. 2004. "The European Parliament and Transnational Political Representation: Party Groups and Political Conflict." Europäische Politik .

Gallagher, Michael. 1988. Introduction. In Candidate Selection in a Comparative Perspective, ed. Michael Gallagher and Michael Marsh. London: Sage Publications pp. 1-19.

Harmel, Robert and Kenneth Janda. 1982. Parties and Their Environments: Limits to Reform. New York: Longman.

Hazan, Reuven Y. 2003. "Introduction Does Cohesion Equal Discipline? Towards a Conceptual Delineation." Journal of Legislative Studies 9(4):1-11.

Heckman, James J. 1976. "The Common Structure of Statistical Models of Truncation, Sample Selection and Limited Dependent Variables and a Simple Estimator for Such Models." Annals of Economic and Social Measurement $5(4): 475-492$.

Heckman, James J. and James M. Jr. Snyder. 1997. "Linear Probability Models of the Demand for Attributes with an Empirical Application to Estimating the Preferences of Legislators." The Rand Journal of Economics 28(0 special issue):S142-S189. 
Hermann, Michael, Heiri Leuthold and Hanspeter Kriesi. 1999. "Die politische Landkarte der Schweiz." Das Magazin (40 (9.10.1999)).

Hix, Simon. 2001. "Legislative Behaviour and Party Competition in the European Parliament: An Application of Nominate to the EU." Journal of Common Market Studies 39(4 Nov):663-688.

Hix, Simon, Abdul Noury and Gérard Roland. 2005. "Power to the Parties: Cohesion and Competition in the European Parliament, 1979-2001." British Journal of Political Science .

Hix, Simon, Abdul Noury and Gérard Roland. 2006. "Dimensions of Politics in the European Parliament." American Journal of Political Science 50(2).

Hix, Simon, Abdul Noury and Gérard Roland. 2006 forthcoming. Democracy in the European Parliament. Cambridge: Cambridge University Press.

Honaker, James, Anne Joseph, Gary King, Kenneth Scheve and Naunihal Singh. 1998. "Amelia: A Program for Missing Data." Cambridge: Department of Government, Harvard University (http://polmeth.calpoly.edu/papers98/king98e.pdf).

Hug, Simon. 2003. "Selection Bias in Comparative Research. The Case of Incomplete Datasets." Political Analysis 11(3):255-274.

Hug, Simon and Dominique Wisler. 1998. "Correcting for Selection Bias in Social Movement Research." Mobilization 3(2):141-161.

Hug, Simon and Tobias Schulz. 2006 forthcoming. "Left-Right Positions of Political Parties in Switzerland." Party Politics .

Interparliamentary Union. 1986. Parliaments of the World. A Reference Compendium. London: MacMillan Press.

Jackman, Simon. 2004. "What Do We Learn from Graduate Admissions Committees? A Multiple Rater, Latent Variable Model, with Incomplete Discrete and Continuous Indicators." Political Analysis 12(4):400-424.

Janda, Kenneth. 1980. Political Parties. New York: Free Press.

Jeitziner, Bruno and Tobias Hohl. 1997. "Measuring Political Preferences: Ratings for Members of the Swiss National Council." Revue suisse de science politique 3(4):1-27.

Jones, Mark P. 2002. Explaining the High Level of Party Discipline in The Argentine Congress. In Legislative Politics in Latin America, ed. Scott Morgenstern and Benito Nacif. Cambridge: Cambridge University Press chapter 6, pp. $147-184$.

Kreppel, Amie. 2002. The European Parliament and Supranational Party System. A Study in Institutional Development. New York: Cambridge University Press.

Kriesi, Hanspeter. 2001. "The Federal Parliament: The Limits of Institutional Reform." West European Politics 24(April 2):59-76. 
Ladner, Andreas. 1999. Das Schweizer Parteiensystem und seine Parteien. In Handbuch der Schweizer Politik, ed. Ulrich Klöti, Peter Knoepfel, Hanspeter Kriesi, Wolf Linder and Yannis Papadopoulos. Zürich: Verlag Neue Zürcher Zeitung pp. 213-260.

Ladner, Andreas. 2004. Stabilität und Wandel Von Parteien und Parteiensystemen : Eine Vergleichende Analyse Von Konfliktlinien, Parteien und Parteiensystemen in Den Schweizer Kantonen. Wiesbaden: VS Verlag für Sozialwissenschaften.

Ladner, Andreas and Michael Brändle. 2001. Die Schweizer Parteien im Wandel. Von Mitgliederparteien zu professionalisierten Wählerorganisationen? Zürich: Seismo.

Levitt, Steven D. 1996. "How Do Senators Vote? Disentangling the Role of Voter Preferences, Party Affiliation, and Senator Ideology." American Economic Review 86(3):425-441.

Loewenberg, Gerhard, Peverill Squire and D. Roderick Kiewiet, eds. 2002. Legislatures. Comparative Perspectives on Representative Assemblies. Ann Arbor: University of Michigan Press.

Loewenberg, Gerhard and Samuel C. Patterson. 1979. Comparing Legislatures. Boston: Little, Brown.

Loewenberg, Gerhard and Thomas C. Mans. 1988. "Individual and Structural Influences on the Perception of Legislative Norms in Three European Parliaments." American Journal of Political Science 32(1 (Feb.)):155-177.

Londregan, John. 2000. Legislative Institutions and Ideology in Chile. New York: Cambridge.

Lüthi, Ruth, Luzius Meyer and Hans Hirter. 1991. Fraktionsdisziplin und die Vertretung von Partiukulärinteressen im Nationalrat. In Das Parlament "Oberste Gewalt des Bundes"?, ed. Parlamentsdienst. Bern: Haupt pp. 5371.

Maddala, G.S. 1983. Limited Dependent and Qualitative Variables in Econometrics. Cambridge: Cambridge University Press.

Morgenstern, Scott. 2003. Patterns of Legislative Politics : Roll Call Voting in Latin America and the United States. Cambridge: Cambridge University Press.

Nacif, Benito. 2002. Understanding Party Discipline in the Mexican Chamber of Deputies: The Centralized Party Model. In Legislative Politics in Latin America, ed. Scott Morgenstern and Benito Nacif. Cambridge: Cambridge University Press chapter 9, pp. 254-286.

Noury, Abdul G. 2002. "Ideology, Nationality and Euro-Parliamentarians." European Union Politics 3(1):33-58.

Persson, Torsten and Guido Enrico Tabellini. 2003. The Economic Effects of Constitutions (Munich Lectures in Economics). Cambridge: MIT Press. 
Poole, Keith. 2005. Spatial Models of Parliamentary Voting. New York: Cambridge University Press.

Poole, Keith A. and Howard Rosenthal. 1997. Congress. A Political-Economic History of Roll Call Voting. Oxford: Oxford University Press.

Poole, Keith and Howard Rosenthal. 1985. "A Spatial Model for Legislative Roll Call Analysis." American Journal of Political Science 29:357-384.

Rice, Stuart A. 1925. "The Behavior of Legislative Groups: A Method of Measurement." Political Science Quarterly 40(1):60-72.

Saalfeld, Thomas. 1995. On Dogs and Whips: Recorded Votes. In Parliaments and Majority Rule in Western Europe, ed. Herbert Döring. New York: St. Martin's Press pp. 528-565.

Skjaeveland, Asbjorn. 1999. "A Danish Party Cohesion Cycle." Scandinavian Political Studies 22(2):121-136.

Snyder, James M. Jr. 1992. "Committee Power, Structure-Induced Equilibrium, and Roll-Call Votes." American Journal of Political Science 36(1):1-30.

Vasella, Marco. 1956. Die Partei- Fraktionsdisziplin als staatsrechtliches Problem. Winterthur: Verlag P.G. Keller.

Voeten, Erik. 2000. "Clashes in the Assembly." International Organization $54(2): 185-215$.

Von Wyss, Moritz. 2003. Die Namenabstimmung im Ständerat: Untersuchung eines parlamentarischen Mythos. In Nachdenken über den demokratischen Staat und seine Geschichte. Beiträge für Alfred Kölz, ed. Isabelle Häner. Zürich: Schulthess pp. 23-47. 